\title{
Expression pattern of the human $A B C$ transporters in pluripotent embryonic stem cells and in their derivatives
}

\begin{tabular}{|c|c|}
\hline Journal: & Cytometry: Part B - Clinical Cytometry \\
\hline Manuscript ID: & $13-077$ \\
\hline Wiley - Manuscript type: & Original Article \\
\hline Date Submitted by the Author: & 02-Sep-2013 \\
\hline Complete List of Authors: & $\begin{array}{l}\text { Erdei, Zsuzsa; Research Centre for Natural Sciences, Hungarian Academy } \\
\text { of Sciences, Institute of Molecular Pharmacology } \\
\text { Lőrincz, Réka; Semmelweis University and National Blood Service, } \\
\text { Molecular Biophysics Research Group of the Hungarian Academy of } \\
\text { Sciences } \\
\text { Szebényi, Kornélia; Research Centre for Natural Sciences, Hungarian } \\
\text { Academy of Sciences, Institute of Molecular Pharmacology } \\
\text { Péntek, Adrienn; Research Centre for Natural Sciences, Hungarian } \\
\text { Academy of Sciences, Institute of Molecular Pharmacology } \\
\text { Varga, Nóra; Research Centre for Natural Sciences, Hungarian Academy of } \\
\text { Sciences, Institute of Molecular Pharmacology } \\
\text { Likó, István; Gedeon Richter Plc, Pharmacology and Drug Safety Research } \\
\text { Várady, György; Research Centre for Natural Sciences, Hungarian } \\
\text { Academy of Sciences, Institute of Molecular Pharmacology; Semmelweis } \\
\text { University and National Blood Service, Molecular Biophysics Research } \\
\text { Group of the Hungarian Academy of Sciences } \\
\text { Szakács, Gergely; Research Centre for Natural Sciences, Hungarian } \\
\text { Academy of Sciences, Institute of Enzimology } \\
\text { Orbán, Tamás; Chemical Technology Transfer Ltd., ; Research Centre for } \\
\text { Natural Sciences, Hungarian Academy of Sciences, Institute of Molecular } \\
\text { Pharmacology } \\
\text { Sarkadi, Balazs; Research Centre for Natural Sciences, Hungarian Academy } \\
\text { of Sciences, Institute of Molecular Pharmacology; Semmelweis University } \\
\text { and National Blood Service, Molecular Biophysics Research Group of the } \\
\text { Hungarian Academy of Sciences } \\
\text { Apáti, Ágota; Semmelweis University and National Blood Service, Molecular } \\
\text { Biophysics Research Group of the Hungarian Academy of Sciences; } \\
\text { Research Centre for Natural Sciences, Hungarian Academy of Sciences, } \\
\text { Institute of Molecular Pharmacology }\end{array}$ \\
\hline Key Words: & $\begin{array}{l}\text { human pluripotent stem cell, Mesenchymal cell, Cardiomyocyte, Neural } \\
\text { cells, ABC transporters, Pluripotency }\end{array}$ \\
\hline Controlled Key Words: & Stem cells, Flow Cytometry, Mesenchymal cells, Microscopy \\
\hline
\end{tabular}




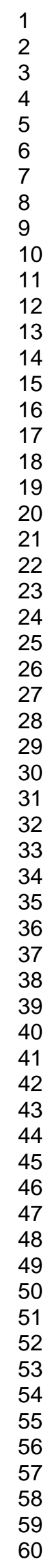

SCHOLARONE ${ }^{m}$

Manuscripts

John Wiley and Sons, Inc. 


\title{
Expression pattern of the human $\mathrm{ABC}$ transporters in pluripotent embryonic stem cells and in their derivatives
}

\author{
Zsuzsa Erdei ${ }^{1}$, Réka Lőrincz ${ }^{3}$, Kornélia Szebényi ${ }^{1}$, Adrienn Péntek ${ }^{1}$, Nóra Varga ${ }^{1}$, István \\ Likó $^{4}$, György Várady ${ }^{1,3}$, Gergely Szakács ${ }^{2}$, Tamás I. Orbán ${ }^{1,5}$, Balázs Sarkadi ${ }^{1,3}$, and Ágota \\ Apáti $^{1,3}$
}

${ }^{1}$ Institute of Molecular Pharmacology, Research Centre for Natural Sciences, Hungarian Academy of Sciences, Budapest, Hungary;

${ }^{2}$ Institute of Enzimology, Research Centre for Natural Sciences, Hungarian Academy of Sciences, Budapest, Hungary;

${ }^{3}$ Molecular Biophysics Research Group of the Hungarian Academy of Sciences, Semmelweis University and National Blood Service, Budapest, Hungary;

${ }^{4}$ Pharmacology and Drug Safety Research, Gedeon Richter Plc, Budapest, Hungary

${ }^{5}$ Chemical Technology Transfer Ltd., Budapest, Hungary

Corresponding author: Ágota Apáti, Institute of Molecular Pharmacology, Research Centre for Natural Sciences, Hungarian Academy of Sciences, and National Blood Service, Budapest, Hungary, Diószegi 64, Budapest, 1113, Hungary, Phone: 36-1-372-4355, Fax: 36$1-372-4353$ 


\section{Abstract}

Background: ATP-binding Cassette (ABC) transporters have key roles in various physiological functions as well as providing chemical defense and stress tolerance in human tissues. In this study we have examined the expression pattern of all $\mathrm{ABC}$ proteins in pluripotent human embryonic stem cells (hESCs) and in their differentiated progenies. We paid special attention to the cellular expression and localization of multidrug transporter $\mathrm{ABC}$ proteins.

Methods: Stem cell differentiation was carried out without chemical induction or cell sorting, and specialized cell types were separated mechanically. Cellular features regarding pluripotency and tissue identity, as well as $\mathrm{ABC}$ transporter expression were studied by flow cytomtery, immuno-microscopy and qPCR-based low-density arrays.

Results: Pluripotent hESCs and differentiated cell types (cardiomyocytes, neuronal cells and mesenchymal stem cells) were distinguished by morphology, immunostaining markers and selected mRNA expression patterns. We found that the mRNA expression levels of the 48 human $\mathrm{ABC}$ proteins also clearly distinguished the pluripotent and the respective differentiated cell types. When multidrug and lipid transporter ABC protein expression was examined by using well characterized specific antibodies by flow cytometry and confocal microscopy, the protein expression data corresponded well to the mRNA expression results. Moreover, the cellular localization of these important human $\mathrm{ABC}$ transporter proteins could be established in the pluripotent and differentiated hESC derived samples.

Conclusions: These studies provide valuable information regarding $\mathrm{ABC}$ protein expression in human stem cells and their differentiated offspring. The results may also help to obtain further information concerning the specialized cellular functions of selected $\mathrm{ABC}$ transporters. 


\section{Introduction}

The $\mathrm{ABC}$ protein family is present from bacteria to humans, and the 48 human $\mathrm{ABC}$ proteins include several transporters, channels, as well as non-membrane proteins (1). During the past decades a large amount of information became available about the expression and function of these human proteins, while there are still numerous unresolved questions in this field. We have shortly summarized the recent knowledge about the human ABC proteins in Supplementary Table 1.

Certain ABC transporters form a special network of chemo-defense system, as these ATP-dependent active transporters extrude a wide variety of substrates from the cells, including endo- and xenobiotics. While these $\mathrm{ABC}$ transporter (with a key role of $\mathrm{ABCB} 1 / \mathrm{Pgp}, \mathrm{ABCC} 1 / \mathrm{MRP} 1$ and $\mathrm{ABCG} 2 / \mathrm{BCRP})$ proteins play an important role in protecting our body, they are also involved in causing multidrug resistance in cancer cells $(2,3)$. One member of these multidrug transporters, ABCG2, has been shown to play a major role in the protection of stem cells against toxic compounds. In addition, the ABCB6 protein has been indicated to play a major role in the defense against toxic heme derivatives, while the ABCA1 protein has a key role in the extrusion of excess cellular lipid derivatives, especially cholesterol (see refs (4-9)).

Since the human embryonic stem cells (hESC) require special protection during development, and some of the differentiated tissues are also well protected against toxic agents, an important task is to follow the changes in the expression and localization of the $\mathrm{ABC}$ multidrug transporters during these early developmental processes.

In our previous studies we have shown that the HUES9 embryonic stem cells express the ABCG2 protein at the cell surface (10), and this transporter has an important role in defending the HUES9 cells during stress conditions (5). In the current work we have examined the full pattern of 48 human ABC protein mRNA expression levels by qPCR-based microarray, in order to provide information about changes in their tissue expression patterns in undifferentiated and selectively differentiated hES cells. We have also followed the expression of selected $\mathrm{ABC}$ transporter proteins by flow cytometry and immunostaining during early human cell differentiation. In addition to provide basic information about $\mathrm{ABC}$ protein expression, these studies also allowed to examine the cellular localization of these transporter proteins which was not exactly known for embryonic stem cells and their derivates. 


\section{Materials and Methods}

\section{Cell culture and differentiation}

The hES cell line HUES9 (originally provided by Dr. Douglas Melton, Harvard University) were maintained on mitotically inactivated mouse embryonic fibroblasts (MEF) and spontaneous differentiation were performed via embryoid body (EB) formation as described previously (11). After 6 days embryoid bodies were placed onto gelatin coated 24 well plates, where they attached to the surface and underwent spontaneous differentiation. The desired cell types were separated as follows:

Some of the EB-outgrowths start spontaneously beating within a few days post-plating. These rhythmically contracting areas were isolated mechanically and hES cell-derived cardiomyocytes were re-plated on gelatin coated 8 well confocal chambers or harvested to RNA isolation. Neuronal progenitor cells with rosette-like morphology were mechanically isolated for generation of hES cell-derived neural cells, between days 8 and 10 . These rosettes were able to re-attach onto gelatin coated surfaces and continue their further differentiation to mature neural cell types. The RNA isolation and immunostaining were performed at day 24 .

The mesenchymal stem cell like ( $\mathrm{MSCl}$ ) cells were generated and maintained as described previously (12). For more details see the Supplementary Methods.

\section{Flow cytometry}

Single cell suspensions were prepared by gentle trypsinization, and the cells were labeled in PBS containing $0.5 \%$ bovine serum albumin with appropriate antibodies. In all hESC samples an anti-mouse Sca-1 (Ly-6A/E) (FITC or PE, BD Pharmingen) antibody was employed for gating out the positively labeled mouse feeder cells.

We used the following directly labeled anti-human antibodies: SSEA4-APC and PODXLPE (R\&D Systems) for investigation of pluripotency. For indirect staining of $A B C$ transporters the following monoclonal antibodies were applied: 5D3 (BD Pharmingen) for ABCG2, MRK16 (Alexis Biochemicals) for ABCB1, anti-Lan (OSK43 (generated and kindly provided by Hideo Takahashi Japanese Red Cross Osaka Blood Center, Japan) (13)) for ABCB6, R1 (Abcam) for ABCC1 and AB H10 (Abcam) for ABCA1 labeling. The 5D3 labeling was performed in the presence of Ko143, a specific inhibitor of ABCG2, which maximizes 5D3 binding (14). Control staining with appropriate isotype-matched control mAbs was included. For fixation and permeabilization of the cells the Fix\&Perm (Invitrogen) solution was used, according to the manufacturer's instruction. Samples were analyzed by a BD FACSCantoII flow cytometer (Becton Dickinson Immunocytometry Systems [BDIS]). For more details see the Supplementary Methods. 


\section{Immuno-cytochemical staining}

Immunostaining of all cell types was performed as described previously (10), except the cell surface labeling of ABCG2 which was carried out as described by (5). For labeling of pluripotent and differentiation markers the following primary antibodies were applied: Oct4 (SantaCruz), Nanog, SSEA4 and PODXL (RnD Systems) cardiac Troponin-I (Sigma), Nestin (Abcam), $\beta$-III Tubulin (RnD Systems) and CD-44-FITC (BD Pharmigen). The ABC transporters were studied by the same antibodies used for flow cytometry. Hoechst33342 (Invitrogen) was used for nuclear staining. The stained samples were examined by an Olympus FV500-IX confocal laser scanning microscope. For more details see the Supplementary Methods.

\section{Gene expression analysis}

Total RNA was isolated from the cells using the Trizol reagent (Life Technologies). RNA integrity was checked by standard gel electrophoresis, RNA concentration was determined by spectrophotometry using a NanoDrop 2000 Spectrophotometer (Thermo Scientific). Gene expression profiles were determined by analysing TaqMan ${ }^{\circledR}$ Low Density Arrays (TLDA cards, Life Technologies) designed for mesasuring pluripotency marker genes (TaqMan ${ }^{\circledR}$ Array Human Stem Cell Pluripotency Panel, cat. \#: 4385344) or ABC transporters (TaqMan ${ }^{\circledR}$ Array Human ABC Transporter Panel, cat. \#: 4378700). Briefly, 500 ng of total RNA was used to prepare cDNA samples using the Reverse Transcription System Kit (Promega), according to the manufacturer's instruction. cDNA samples corresponding to 100ng of total RNA were combined with $2 \mathrm{X}$ TaqMan ${ }^{\circledR}$ Gene Expression Master Mix and loaded on one channel of the appropriate TLDA card; real-time PCR reactions were run on a $7900 \mathrm{HT}$ System according to the manufacturer's protocol (Life Technologies). For data analysis, the DataAssist $^{\mathrm{TM}}$ Software v3.0 (Life Technologies) was used. Gene expression values were determined by the $\Delta \Delta \mathrm{Ct}$ method using multiple endogenous control genes on the TLDA cards (ACTB and GAPDH genes for the pluripotency array data and PRLP0 and PPIA genes for the $\mathrm{ABC}$ transporter array data). The average linkage clustering method was applied to analyze the expression data and to calculate Pearson's correlation values to define distances of our samples sets. 


\section{Results}

\section{Differentiation of hES cells - characterization by differentiation markers}

For studying the expression of human $\mathrm{ABC}$ proteins in pluripotent cells and in their differentiated derivatives, we have generated cardiac cells, mesenchymal-like stem cells (MSCls (12)) and neural cells from the HUES9 cells, by using a method of spontaneous differentiation, via EB formation (Supplementary Fig. 1). With this method the desired cell types could be generated from hESC without the addition of special chemicals, and the selection of the differentiated progenies was performed by enzymatic digestion and/or mechanical selection, without applying any drug selection or cell sorting. All the differentiated cell types were cultured in the same media and under similar conditions (see Materials and Methods). These uniform conditions were used because the expression levels and localization of several $\mathrm{ABC}$ proteins have been shown to be influenced by chemical inducers, selection drugs or antibiotics (see ref. $(15,16)$ ).

When selecting various tissue types, we performed a detailed phenotypic characterization of the parental and differentiated cell types, in order to assure that any further analysis should be performed by using properly selected populations. This characterization included the investigation of several cell type specific markers by flow-cytometry and immunocytochemistry.

As shown in Figure 1A, by flow cytometry studies we found that the pluripotent hES cells (HUES9) highly expressed the SSEA-4 and PODXL pluripotency markers on the cell surface. Using immunostaining and confocal microscopy, we could clearly show the presence of the nuclear pluripotency markers, Oct4 and Nanog, as well as the cellular membrane staining of SSEA-4 and PODXL (Fig. 1B).

During differentiation studies, cell surface markers for MSCls were analyzed as described in detail in our previous work (see (12)). In all cases, immunostaining revealed proper separation of cells showing positive staining for representative markers of cardiac (cardiac troponin-cTNI), neural (neuron specific tubulin- $\beta$-III tubulin and Nestin) and mesenchymal (CD44) cell types (Figure 1C).

After this phenotypic selection and verification we have analyzed the mRNA expression patterns of the selected cell types by using a TLDA pluripotency array. Besides the differentiated cell types, the common progenies of the differentiated cells (mesenchymal, cardiac and neural) from 6 days old EBs were included in the further investigation. The array included 36 pluripotency, 19 mesoderm, 13 ectoderm, 17 endoderm and 4 trophectoderm markers, along with several housekeeping genes. An overview of these data (summarized in 
supplementary table 2) is demonstrated in a heat-map (Fig. 2A), showing relative gene expression levels. The cluster analysis (see Methods), documented in Fig. 2B, shows close correlation of the mRNA expression pattern with the differentiation status of the cell samples. As shown, the biological parallels (for $\mathrm{hESC}$ and $\mathrm{MSCl}$ ) clustered together, while the undifferentiated hESC samples are clearly separated from the partially differentiated sample (6 days EB). The mRNA clusters of the differentiated cell types are noticeably different from that of the hESCs and from one another and the biological replicates of the most differentiated cell types (the $\mathrm{MSCl}$ cells, after 80 days of differentiation) are located away from the undifferentiated cells with the longest distance in the dendrogram. As shown by the highest expression levels found in the pluripotency array data, the hES cells showed high levels of the pluripotency mRNA markers, while the derivative cells showed upregulated levels of the proper lineage-specific markers (Fig 2C).

2. ABC transporter expression in pluripotent and differentiated hES cells - flow cytometry studies

In these experiments we investigated the $\mathrm{ABC}$ transporter expression in the pluripotent and differentiated cells at the protein level. The application of specific and properly reactive antibodies is a crucial question in these experiments. Especially in the case of the flow cytometry studies, we used antibodies against extracellular epitopes to examine the expression and cell surface localization of ABCG2 (mAb 5D3), ABCB1 (mAb MRK16), and ABCB6 (mAb OSK43). However, most of the antibodies recognizing human $\mathrm{ABC}$ transporters have been generated against intracellular epitopes, and in several experiments we have used such antibodies (see Methods). In each case, the specific protein recognition was assured by examining various cell types overexpressing these $A B C$ transporters (suppl. fig 2a).

The two major cell types in which ABC transporter expression could be studied without major cellular damage were the undifferentiated hES cells and the MSCs. In these cell types we focused on the expression of $\mathrm{ABC}$ multidrug or lipid transporters with key roles in cellular chemodefense and stress response. As shown in Fig. 3, in the case of ABCB1, ABCB6 and ABCG2 we used the respective antibodies recognizing extracellular epitopes, while in the case of $\mathrm{ABCC} 1$ and $\mathrm{ABCA} 1$ we employed antibodies generated against intracellular protein domains.

Fig. 3A shows flow cytometry detection of five ABC transporters (ABCB1, ABCB6, ABCG2, ABCC1 and ABCA1) in hESCs under non-permabilized conditions using antibodies recognizing external epitopes; while panel B of Fig. 3 shows similar measurements after 
permeabilization of hESCs. As documented, in all cases we found a very low level expression in the non-permeabilized cells except ABCG2 which showed elevated level of cell surface expression, while a slight increase in the apparent expression of all these transporters, especially ABCA1 could be found in the permeabilized hESCs. Only ABCG2 expression level showed an apparent reduction under these conditions, showing that the 5D3 antibody binding was reduced by the applied fixation-permeabilization.

Fig. 4 documents similar studies carried out with hES-derived MSCls by flow cytometry. In this case the expression levels of all studied transporters were negligible without permeabilization (Fig 4 A), but were well detectable in the permeabilized cells in the case of $\mathrm{ABCB} 6, \mathrm{ABCC} 1$, and especially of $\mathrm{ABCA} 1$. It is important to note that $\mathrm{ABCG} 2$ expression was not detectable in these cells, with or without permeabilization.

In the case of $\mathrm{ABCB} 1$ and $\mathrm{ABCB} 6$ (antibodies reacting with external membrane epitopes) the potential expression of these proteins in intracellular membrane compartments may be suggested by these data. Since the $\mathrm{ABCC} 1$ and $\mathrm{ABCA} 1$ antibodies recognize intracellular epitopes, the increased protein levels found in the permeabilized cells most probably correspond to increased general expression levels, and in this case the plasma membrane or intracellular membrane expression levels cannot be distinguished.

3. ABC transporter expression in pluripotent and differentiated hES cells immunomicroscopy studies

Flow cytometry examinations could not be performed with vulnerable cell types such as cardiomyocytes and neural cells, without injuring the cells. Comparative examination of the hESC and hESC derived cell types by immunohistochemistry is thus an additional method to characterize protein expression and yield more informative cellular localization data than flow cytometry.

In Fig 5 we summarize the results of the immunostaining experiments. This figure compiles representative data for each cell type and for the above described antibodies recognizing selected ABC transporters. As shown in Supplementary Figure 2B, we have examined several selected cell types, overexpressing these $\mathrm{ABC}$ transporters, as positive controls (see also M\&M).

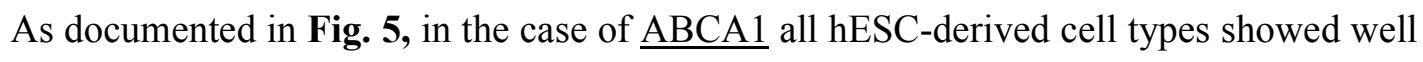
measurable expression, and in the undifferentiated hESCs and the MSCls, the expression was homogenously high showing both plasma membrane and cytosolic localization. In contrast, only a small number of cardiac and neural cells showed ABCA1 expression, and this 
expression was mostly localized in the cytosol. In the case of $\underline{\mathrm{ABCB} 1}$, we found measurable expression only in the differentiated cardiac and neural cell types, which was in agreement with the flow cytometry data indicating no ABCB1 expression in the undifferentiated hESCs and the MSCls. The $\underline{\mathrm{ABCB} 6}$ protein was expressed ubiquitously in all of the examined cell types, and the expression was found in intracellular compartments. These data are again in line with the flow cytometry results which also indicated intracellular expression of this protein. For $\underline{\mathrm{ABCC} 1}$, a well measurable expression could be observed for most of the cell types, except for the cardiac cells, showing a much lower protein level. In all cases, ABCC1 expression was detected in the plasma membrane compartment.

As shown earlier in Fig. 3, in the undifferentiated hES cells high level of ABCG2 protein expression was detected on the cell surface by flow cytometry and the immunostaining experiments shown in Fig. 5 verified this phenomenon. In contrast, we could not detect a significant ABCG2 expression in the differentiated MSCl cell types and some expression could be detected on cardiac and neural cultures however this expression was confined to the border of tissues. In Fig. 5, we have also included immunostaining data for the ABCC6 protein, as this transporter has been indicated to play an important role in cardiac tissues $(17,18)$. However, we could not detect ABCC6 expression in any of the examined hESCderived cell types.

\section{ABC protein $m R N A$ expression in pluripotent and differentiated hES cells}

Because of the lack of reliable antibodies and staining protocols for numerous human $\mathrm{ABC}$ proteins, a systematic analysis can only be performed for the respective mRNA expression levels. For this purpose we used a quantitative RT-PCR technology and ABC protein specific microarray, and examined the same mRNA samples as used in the pluripotency array analysis (see Fig. 2), obtained from pluripotent hESCs and the differentiated cell types. A visual overview of these gene expression data is demonstrated in a heat-map (Fig. 6 A), while the original Ct data are presented in the Supplementary Table 3.

When analyzing the $\mathrm{ABC}$ mRNA array we observed that the expression of $\mathrm{ABC}$ transporters in general showed lower mRNA expression levels than the pluripotency markers (average $\mathrm{Ct}(\mathrm{ABC})=33,6 \pm 2,8$; average $\mathrm{Ct}$ (pluri) $=21,6 \pm 7,6$ ), as compared to the similar level measured for the expression of the housekeeping genes. Since membrane protein expression usually requires long term expression of relatively smaller amount of proteins, this result was in accordance with our expectations. 
Cluster analysis based on $\mathrm{ABC}$ protein expression patterns is shown in Fig 6B. Remarkably, clustering based on ABC transporter profiles was found to be similar to the hierarchy defined by pluripotency markers (see Fig. 2), indicating that all the examined cell types have characteristic expression patterns (fingerprints) for the $\mathrm{ABC}$ proteins, depending on the cell maturation status. As shown in Fig $\mathbf{6 C}$, some of the $\mathrm{ABC}$ proteins showed similar (medium) level of expression in all cell types (Fig 6C left panel), although most of these ABC proteins are not well described transporters, and some are not even membrane proteins (see Suppl. table 1). These data suggest a role of these $\mathrm{ABC}$ proteins in the general maintenance of cellular homeostasis.

In the following analysis, we focused on the recognized ABC membrane transporters, and excluded those proteins which showed high $\mathrm{Ct}$ values, indicating extremely low or no expression (Fig 6C right panel). We compared the relative expression of $\mathrm{ABC}$ transporter mRNAs in differentiated cells to those in undifferentiated hES cells (Supplementary table 4).

As shown in Fig7 and presented in supplementary table 4, we found that most of the $\mathrm{ABC}$ transporters were expressed at significantly higher level (although in different magnitudes, see Fig 7A and B) in the differentiated cell types than in the pluripotent hESCs. When analyzing the cell-type dependent expression, we found that several ABC transporter mRNA levels showed large increase in differentiated progenies. These included the expression of $\mathrm{ABCA} 8, \mathrm{ABCC} 3, \mathrm{ABCC} 9$, and $\mathrm{ABCG} 1$. In contrast, there were several transporter mRNA expression levels characteristic for certain cell types: changes of ABCB1 and ABCC6 expressions were higher in cardiac cells and ABCA4 was higher in neural cells compared to hESC (Fig 7A). Note, that the only ABC transporter which showed a decreased expression level in all differentiated cell types was ABCG2 (Fig 7B).

This cell type-specific expression indicates a possible role of these proteins in the differentiated tissues and allows a further characterization of their physiological roles. 


\section{Discussion}

ATP-binding Cassette (ABC) transporters play an important role in various physiological functions, maintain cellular homeostasis, and provide defense mechanism against toxic endoand xenobiotics. These ABC transporters work in a general defense network system, having overlapping functions and substrate specificity. Based on their promiscuous recognition of toxic agents, they can functionally substitute each other. While many of the ABC multidrug transporters also have broad tissue distribution, their expression levels may provide a tissuespecific "fingerprint", corresponding to special metabolic or other cellular functions, as well as tolerance against stress and drugs.

In this study we have examined the protein level and cellular localization of the major multidrug transporters, as well as the mRNA expression pattern of all $48 \mathrm{ABC}$ proteins in pluripotent human embryonic stem cells and in their selected, differentiated progenies. In order to investigate the human $\mathrm{ABC}$ transporter expression "fingerprint" in differentiating cells, we have used and characterized an experimental system involving four human cell types of isogenic origin. We have cultured human pluripotent hESCs, and in a spontaneous differentiation model generated well separable differentiated cell types, including cardiac cells, neural cells and MSC-like cells. The major advantage of this system is that the hES cells and the differentiated progenies have the same genetic background and cell differentiation did not involve major changes in the culturing conditions.

In these experiments first we examined pluripotency and tissue-specific marker protein expression in the selected cell types by flow cytometry and immunostaining. We have also carried out the investigation of the mRNA expression pattern of a wide range of pluripotency and differentiation markers by using RT-PCR based quantitative arrays. These studies established a proper characterization of the respective cell types.

When looking for $\mathrm{ABC}$ protein expression, we found that the mRNA expression levels of all the 48 human $\mathrm{ABC}$ proteins also clearly distinguished the pluripotent and the respective differentiated cell types. According to recent studies, distinct $\mathrm{ABC}$ protein patterns were observed when hESCs (HES2 and HES3) were compared to hematopoietic stem cells, unrestricted somatic stem cells and mesenchymal stem cells (19). It has also been shown that mRNA expression levels are different in hESCs and hESC-derived hMSCs (20). However none of these studies have investigated the $\mathrm{ABC}$ transporter expression at protein level. In order to perform a detailed characterization, we selected several key $A B C$ transporters involved in multidrug resistance, providing defense against stress conditions, and modulating cellular lipid metabolism. These transporters were examined by using well characterized 
specific antibodies both in flow cytometry and confocal microscopy experiments. This way the cellular expression pattern and also the subcellular localization of these important human $\mathrm{ABC}$ transporters could be established in the pluripotent and differentiated hES cell derived samples. It is important to note that the obtained $\mathrm{ABC}$ transporter protein expression data closely corresponded to the respective mRNA expression results.

During our investigations, we found that the most prevalent multidrug transporter in the undifferentiated hES cells, in accordance with previous data, was the ABCG2/BCRP protein. This protein is expressed on the cell surface and, although this expression is heterogeneous, may significantly contribute to the defense mechanisms in pluripotent stem cells (sees refs. $(10,19-22))$. Another multidrug transporter found at low levels in the undifferentiated cells was $\mathrm{ABCC} 1$ (on the cell surface), while we could not detect $\mathrm{ABCB} 1 / \mathrm{MDR} 1$ in this cell type. Two other ABC transporters found to be expressed in the hES cells were ABCA1, an important player in lipid/cholesterol extrusion, and $\mathrm{ABCB} 6$, a potential player in protecting against toxic heme derivatives. Interestingly, this transporter, noted to be also in the plasma membranes of various cells $(23,24)$, showed only intracellular expression in all cell types examined here.

In the human ES-derived neural cells we observed high level expression for ABCB6 and $\mathrm{ABCC} 1$, and in certain cell regions for that of $\mathrm{ABCA} 1$ and $\mathrm{ABCB} 1$. In the cardiomyocytes high level expression of ABCB6 and lower levels for ABCB1 and ABCA1 were observed. Interestingly, certain cells in the external regions of cardiac and neural tissue samples also showed ABCG2 expression. In the MSCs a predominant, but mostly intracellular expression was observed for $\mathrm{ABCA} 1, \mathrm{ABCB} 6$ and $\mathrm{ABCC} 1$, while there was no measurable expression for $\mathrm{ABCB} 1$ or $\mathrm{ABCG} 2$. As of note, we did not find any significant $\mathrm{ABCC} 6$ expression at protein level in any of the cell types examined here.

As a summary, these studies may provide important information for a selective ABC protein expression pattern in human stem cells and in their differentiated offsprings. However, further studies are needed for the establishment of specialized inter-tissue and inter-organ distribution, as well as for the cellular functions of the key human $\mathrm{ABC}$ transporters during early human development.

\section{Acknowledgments}

The authors are indebted to Beáta Haraszti for excellent technical assistance, András Váradi and László Homolya for providing positive control cell lines and antibodies and Dr. Anna Brózik for useful suggestions. The authors appreciate the gift of HUES9 cell line by Dr. 
Douglas Melton, HHMI. Research in our laboratory was supported by the OTKA (NK83533), KTIA_AIK_12-1-2012-0025 and the KMR_12-1-2012-0112 grants.

\section{Disclosure statement}

No competing financial interests exist.

\section{References}

1. Dean M, Rzhetsky A, Allikmets R. The human ATP-binding cassette (ABC) transporter superfamily. Genome Res 2001;11(7):1156-66.

2. Hyde SC, Emsley P, Hartshorn MJ, Mimmack MM, Gileadi U, Pearce SR, Gallagher MP, Gill DR, Hubbard RE, Higgins CF. Structural model of ATP-binding proteins associated with cystic fibrosis, multidrug resistance and bacterial transport. Nature 1990;346(6282):362-5.

3. Sarkadi B, Homolya L, Szakacs G, Varadi A. Human multidrug resistance ABCB and ABCG transporters: participation in a chemoimmunity defense system. Physiol Rev 2006;86(4):1179-236.

4. Ding XW, Wu JH, Jiang CP. ABCG2: a potential marker of stem cells and novel target in stem cell and cancer therapy. Life Sci 2010;86(17-18):631-7.

5. Erdei Z, Sarkadi B, Brozik A, Szebenyi K, Varady G, Mako V, Pentek A, Orban TI, Apati A. Dynamic ABCG2 expression in human embryonic stem cells provides the basis for stress response. Eur Biophys J 2012;42(2-3):169-79.

6. Krishnamurthy PC, Du G, Fukuda Y, Sun D, Sampath J, Mercer KE, Wang J, SosaPineda B, Murti KG, Schuetz JD. Identification of a mammalian mitochondrial porphyrin transporter. Nature 2006;443(7111):586-9.

7. Hamza I, Dailey HA. One ring to rule them all: trafficking of heme and heme synthesis intermediates in the metazoans. Biochim Biophys Acta 2012;1823(9):161732.

8. Liu HF, Cui KF, Wang JP, Zhang M, Guo YP, Li XY, Jiang C. Significance of ABCA1 in human carotid atherosclerotic plaques. Exp Ther Med 2012;4(2):297-302.

9. Wenzel JJ, Piehler A, Kaminski WE. ABC A-subclass proteins: gatekeepers of cellular phospho- and sphingolipid transport. Front Biosci 2007;12:3177-93.

10. Apati A, Orban TI, Varga N, Nemeth A, Schamberger A, Krizsik V, Erdelyi-Belle B, Homolya L, Varady G, Padanyi R and others. High level functional expression of the 
ABCG2 multidrug transporter in undifferentiated human embryonic stem cells. Biochim Biophys Acta 2008;1778(12):2700-9.

11. Orban TI, Apati A, Nemeth A, Varga N, Krizsik V, Schamberger A, Szebenyi K, Erdei Z, Varady G, Karaszi E and others. Applying a "double-feature" promoter to identify cardiomyocytes differentiated from human embryonic stem cells following transposon-based gene delivery. Stem Cells 2009;27(5):1077-87.

12. Varga N, Vereb Z, Rajnavolgyi E, Nemet K, Uher F, Sarkadi B, Apati A. Mesenchymal stem cell like ( $\mathrm{MSCl}$ ) cells generated from human embryonic stem cells support pluripotent cell growth. Biochem Biophys Res Commun 2011;414(3):474-80.

13. Helias V, Saison C, Ballif BA, Peyrard T, Takahashi J, Takahashi H, Tanaka M, Deybach JC, Puy H, Le Gall M and others. ABCB6 is dispensable for erythropoiesis and specifies the new blood group system Langereis. Nat Genet 2012;44(2):170-3.

14. Ozvegy-Laczka C, Varady G, Koblos G, Ujhelly O, Cervenak J, Schuetz JD, Sorrentino BP, Koomen GJ, Varadi A, Nemet K and others. Function-dependent conformational changes of the ABCG2 multidrug transporter modify its interaction with a monoclonal antibody on the cell surface. J Biol Chem 2005;280(6):4219-27.

15. Leslie EM, Deeley RG, Cole SP. Multidrug resistance proteins: role of P-glycoprotein, MRP1, MRP2, and BCRP (ABCG2) in tissue defense. Toxicol Appl Pharmacol 2005;204(3):216-37.

16. Takenaka K, Morgan JA, Scheffer GL, Adachi M, Stewart CF, Sun D, Leggas M, Ejendal KF, Hrycyna CA, Schuetz JD. Substrate overlap between Mrp4 and Abcg2/Bcrp affects purine analogue drug cytotoxicity and tissue distribution. Cancer Res 2007;67(14):6965-72.

17. Kavukcuoglu NB, Li Q, Pleshko N, Uitto J. Connective tissue mineralization in Abcc6-/- mice, a model for pseudoxanthoma elasticum. Matrix Biol 2012;31(4):24652.

18. Mungrue IN, Zhao P, Yao Y, Meng H, Rau C, Havel JV, Gorgels TG, Bergen AA, MacLellan WR, Drake TA and others. Abcc6 deficiency causes increased infarct size and apoptosis in a mouse cardiac ischemia-reperfusion model. Arterioscler Thromb Vasc Biol 2011;31(12):2806-12.

19. Tang L, Bergevoet SM, Gilissen C, de Witte T, Jansen JH, van der Reijden BA, Raymakers RA. Hematopoietic stem cells exhibit a specific ABC transporter gene expression profile clearly distinct from other stem cells. BMC Pharmacol 2010;10:12. 
20. Barbet R, Peiffer I, Hutchins JR, Hatzfeld A, Garrido E, Hatzfeld JA. Expression of the 49 human ATP binding cassette (ABC) genes in pluripotent embryonic stem cells and in early- and late-stage multipotent mesenchymal stem cells: possible role of ABC plasma membrane transporters in maintaining human stem cell pluripotency. Cell Cycle 2012;11(8):1611-20.

21. Sawicki WT, Kujawa M, Jankowska-Steifer E, Mystkowska ET, Hyc A, Kowalewski C. Temporal/spatial expression and efflux activity of $\mathrm{ABC}$ transporter, Pglycoprotein/Abcb1 isoforms and Bcrp/Abcg2 during early murine development. Gene Expr Patterns 2006;6(7):738-46.

22. Vieyra DS, Rosen A, Goodell MA. Identification and characterization of side population cells in embryonic stem cell cultures. Stem Cells Dev 2009;18(8):1155-66.

23. Kiss K, Brozik A, Kucsma N, Toth A, Gera M, Berry L, Vallentin A, Vial H, Vidal M, Szakacs G. Shifting the paradigm: the putative mitochondrial protein ABCB6 resides in the lysosomes of cells and in the plasma membrane of erythrocytes. PLoS One 2012;7(5):e37378.

24. Paterson JK, Shukla S, Black CM, Tachiwada T, Garfield S, Wincovitch S, Ernst DN, Agadir A, Li X, Ambudkar SV and others. Human ABCB6 localizes to both the outer mitochondrial membrane and the plasma membrane. Biochemistry 2007;46(33):944352.

25. Lee MN, Roy M, Ong SE, Mertins P, Villani AC, Li W, Dotiwala F, Sen J, Doench $\mathrm{JG}$, Orzalli $\mathrm{MH}$ and others. Identification of regulators of the innate immune response to cytosolic DNA and retroviral infection by an integrative approach. Nat Immunol 2012;14(2):179-85.

26. Paytubi S, Wang X, Lam YW, Izquierdo L, Hunter MJ, Jan E, Hundal HS, Proud CG. $\mathrm{ABC} 50$ promotes translation initiation in mammalian cells. $\mathrm{J}$ Biol Chem 2009;284(36):24061-73.

27. Wanders RJ, Visser WF, van Roermund CW, Kemp S, Waterham HR. The peroxisomal ABC transporter family. Pflugers Arch 2007;453(5):719-34.

28. Zhou S, Schuetz JD, Bunting KD, Colapietro AM, Sampath J, Morris JJ, Lagutina I, Grosveld GC, Osawa M, Nakauchi H and others. The ABC transporter Bcrp1/ABCG2 is expressed in a wide variety of stem cells and is a molecular determinant of the sidepopulation phenotype. Nat Med 2001;7(9):1028-34. 


\section{Figure Legends}

Figure 1. Characterization of HUES9 cells and their derivates by following the expression of selected proteins.

(A) Investigation of the pluripotent state of HUES9 cells by flow cytometry. More than $90 \%$ of the cells show cell-surface SSEA4 and PODXL expression. M1: cell population with marker positivity was gated based on the relevant isotype-matched control mAbs.

(B) Investigation of the pluripotent state of HUES 9 cells by immunomicroscopy. HUES 9 cells were grown on MEF feeder cells for two days in eight-well chambers for confocal microscopy. Co-culture of HUES9 and feeder cells were fixed, permeabilized and stained with the antibodies recognizing the Nanog (red), Oct4 (green), SSEA4 (green) and PODXL (green) markers. Nuclei were counterstained with Hoechst33342 (blue). Nanog and Oct4 transcription factors showed nuclear localization, while SSEA4 and PODXL cell surface markers localized in plasmamembrane.

(C) Investigation of the differentiated forms of HUES9 cells by immunomicroscopy. HUES9derived cell types were differentiated as described in Materials and Methods and were transferred mechanically into eight-well chambers for confocal microscopy. The samples were fixed, permeabilized and stained with antibodies recognizing specific proteins for each cell type; cTNI (green) for cardiac, $\beta$ - III tubulin (green) and Nestin (red) for neural and CD44 (green) for mesenchymal cell type. Nuclei were counterstained with Hoechst33342 (blue).

Figure 2. TLDA analysis of differentiation status of HUES9 cells and their differentiated offspring

(A) Heat map representation of human pluripotency marker gene mRNA expressions in 7 samples of 4 cell types (hESCs a and b, cardiac, neural and MSCs a and b) and the 6 days old EB culture (the common progenitors of differentiated cell types). The pluripotency genes are shown on the y-axis, the 7 samples are ordered on the x-axis with biological replicates ("a" and "b"). The color code ranges from high $(\mathrm{dCt}=-6$, light red) through medium (black), to low $(\mathrm{dCt}=26$, light green $)$ levels of gene expression relative to selected housekeeping genes.

(B) Hierarchical clustering of 7 samples allowing a separation based on differentiation status of the samples.

(C) The highest gene expressions $(5<\mathrm{Ct}>15)$ for each cell type showing the proper characteristics for a given differentiation status. 
Figure 3. Flow cytometry analysis of ABC transporter expression in hES cells.

Single cell suspensions from HUES9 cells were obtained as described in Materials and Methods. Non-viable cells were gated out by 7AAD staining. Monoclonal antibodies specific for $\mathrm{ABCB} 1, \mathrm{ABCB} 6, \mathrm{ABCG} 2, \mathrm{ABCC} 1$ and $\mathrm{ABCA} 1$ were used to detect transporter expression (A) in intact cells (without fixation and permeabilization) and (B) in fixed and permebealized cells (for details see Materials and Methods). R1: cell population with marker positivity was gated based on the relevant isotype-matched control mAbs; MFI: mean fluorescence intensity.

Figure 4. Flow cytometry analysis of $\mathrm{ABC}$ transporter expression on $\mathrm{MSCl}$ cells.

Single cell suspensions from MSCl cells were obtained by gentle trypsinization. Non-viable cells were gated out by 7AAD staining. Monoclonal antibodies specific for ABCB1, ABCB6, ABCG2, ABCC1 and ABCA1 were used to detect transporter expression (A) on intact cells (without fixation and permeabilization) and (B) in fixed and permeabilized cells (for details see Materials and Methods). R1: cell population with marker positivity was gated based on the relevant isotype-matched control mAbs; MFI: mean fluorescence intensity.

Fig. 5 Immuncytochemical detection of ABC transporters in HUES9 cells and their derivatives.

HUES 9 cells were grown on MEF feeder cells for two days in eight-well chambers and HUES9-derived cell types were differentiated as described in Materials and Methods and were transferred mechanically into eight-well chambers for confocal microscopy. The samples were stained with specific antibodies to visualize ABCA1, ABCB1, ABCB6, $\mathrm{ABCC} 1, \mathrm{ABCG} 2$ and $\mathrm{ABCC} 6$ proteins (red) as described in the "Materials and methods" section. Nuclei were counterstained with Hoechst33342 (blue). Stained samples were examined by an Olympus FV500-IX confocal laser scanning microscope.

Figure 6. TLDA analysis of ABC protein gene expression in HUES9 cells and their differentiated offspring

(A) Heat map representation of human ABC protein gene expressions in 7 samples of 4 cell types (hESCs a and b, cardiac, neural and MSCls a and b) and the 6 days old EB culture (the common progenitors of differentiated cell types). The ABC genes are shown on the y-axis, the 7 samples are ordered on the x-axis with biological replicates ("a" and "b"). The color code ranges from high $(\mathrm{dCt}=4$, light red) through medium (black), to low $(\mathrm{dCt}=14$, light green) 
gene expression relative to selected housekeeping genes. (B) Hierarchical clustering of 7 samples allowing a separation based on differentiation status of samples. (C) The listed highest $\mathrm{ABC}$ gene expressions $(27<\mathrm{Ct}>32$, bold $)$ and lowest gene expressions $(\mathrm{Ct}>38$, normal) were common for each cell type showing universal expression pattern for certain $\mathrm{ABC}$ proteins.

Figure 7. Relative gene expressions of ABC transporters in hESC derived cell types as compared to undifferentiated cells.

The relative gene expression levels of each transporter in hESCs are set at 1 and the fold differences in expression are presented on the graph.

Supplementary table 1. Summary of human ABC proteins

For more information see refs (http://humanabc.4t.com/main.htm, (9,25-28))

Supplementary table 2. List of pluripotency gene expression data

The Ct values are given for each cell type. Pluripotency markers (black), mesoderm markers (green), ectoderm markers (blue), endoderm markers (orange), trophectoderm markers (brown), housekeeping genes (italic, black), transcription factors (bold).

Supplementary table 3. List of ABC protein gene expression data

The $\mathrm{Ct}$ values are given for each cell type. The value of 40 indicates the lack of detection/expression of the corresponding mRNA.

Supplementary table 4. ABC transporter expression changes during differentiation towards cardiac, neural and mesenchymal cell types.

Supplementary Figure 1. Differentiation of hES cells via embryoid body system

An outline of the protocol used for the differentiation of human ESCs to cardiac, neural and mesenchymal cell types.

Supplementary Figure 2. Immunostaining for detection of ABC transporters

(A) Single cell suspensions from positive cell types were obtained by gentle trypsinization. Non-viable cells were excluded by 7AAD staining. Monoclonal antibodies specific for $\mathrm{ABCB} 1, \mathrm{ABCB} 6, \mathrm{ABCG} 2, \mathrm{ABCC} 1$ and $\mathrm{ABCA} 1$ were used to detect transporter expression as described in Materials and Methods. R1: cell population with marker positivity was gated based on the relevant isotype-matched control mAbs

(B)The positive cell types were passaged into eight-well chambers for confocal microscopy. The samples were stained with specific antibodies to visualize ABCA1, ABCB1, ABCB6, $\mathrm{ABCC} 1, \mathrm{ABCG} 2$ and $\mathrm{ABCC} 6$ proteins (green) as described in the "Materials and methods" 
section. Nuclei were counterstained with Hoechst33342 (blue). Stained samples were examined by an Olympus FV500-IX confocal laser scanning microscope.

John Wiley and Sons, Inc. 
A

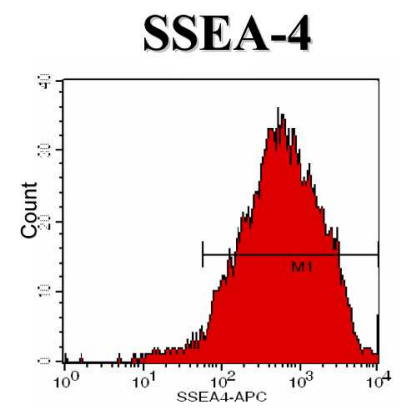

SSEA-4

\section{PODXL}
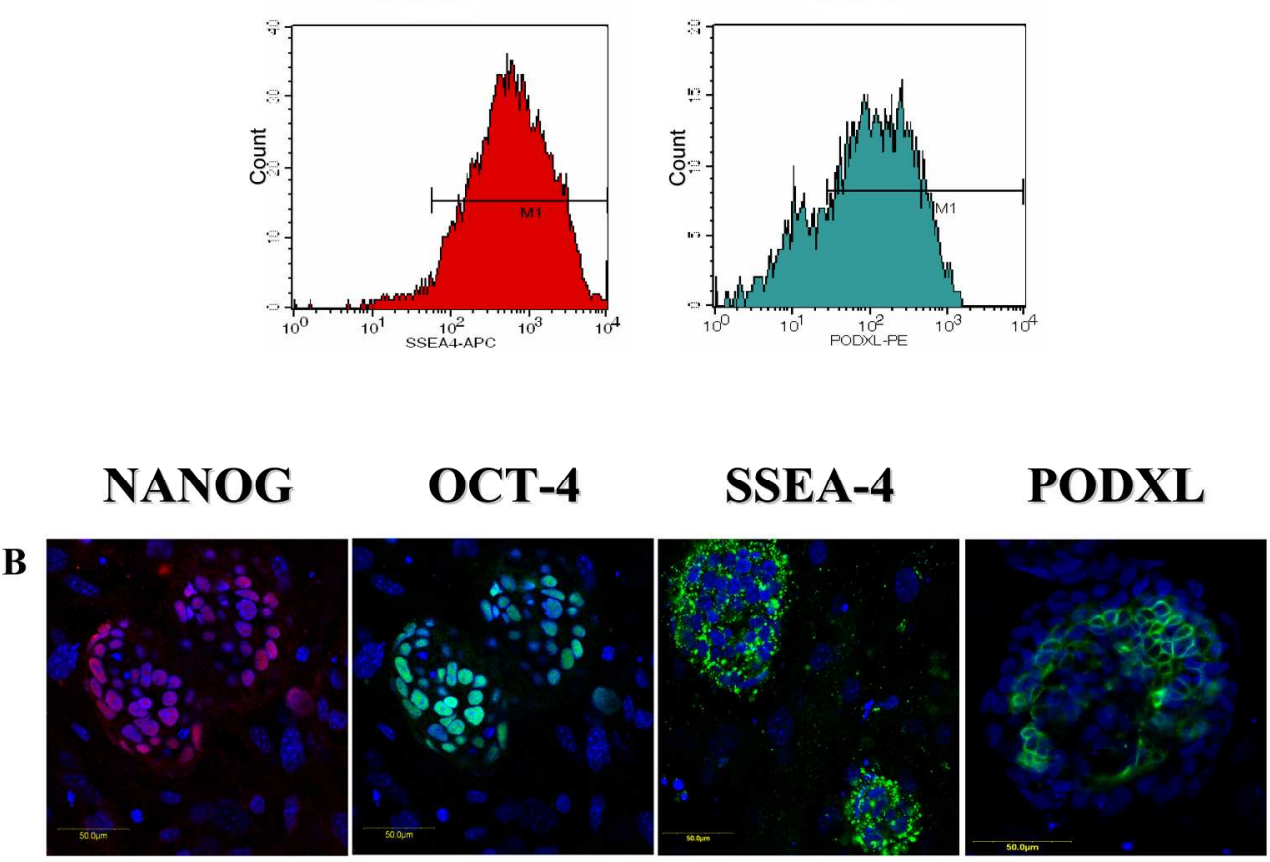

$215 \times 155 \mathrm{~mm}(300 \times 300$ DPI $)$

John Wiley and Sons, Inc. 

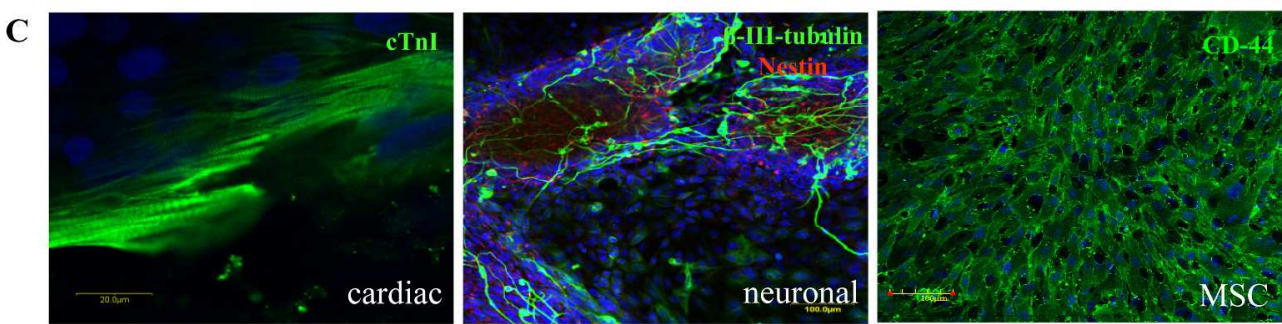

$249 \times 69 \mathrm{~mm}(300 \times 300 \mathrm{DPI})$ 


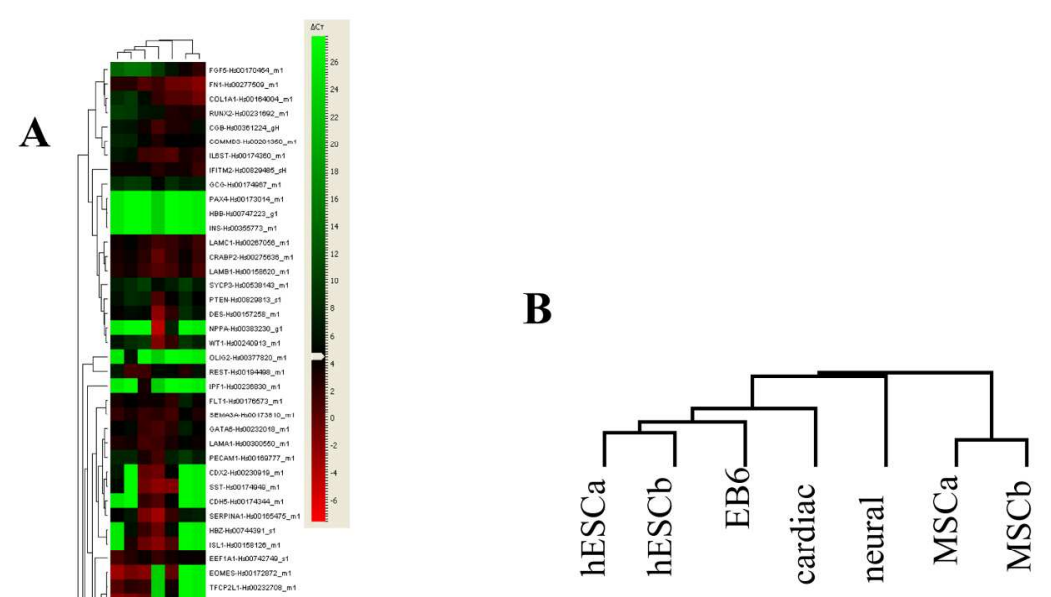

C Highest expression $(5<\mathrm{Ct}>15)$

hES Cardiac Neural MSC

$\begin{array}{llll}\text { FN1 } & \text { AFP } & \text { PAX6 } & \text { FN1 }\end{array}$

LIN28 ACTC SFRP2 COL1A1

Nanog GATA4 AFP LAMB1

DNMT3B COL1A1 SST LAMC1

IFITM1 NPPA FN1 IL6ST

PODXL EBAF EOMES-T IMP2-IGFII

$182 \times 190 \mathrm{~mm}(300 \times 300 \mathrm{DPI})$

John Wiley and Sons, Inc. 
A

hESC
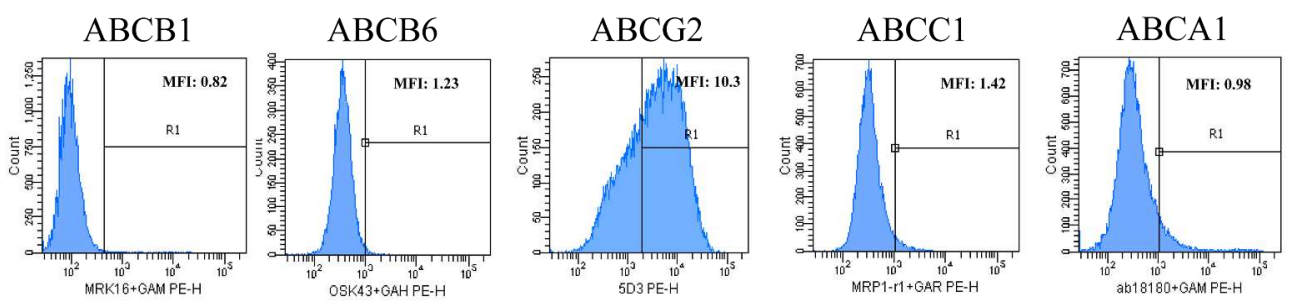

B
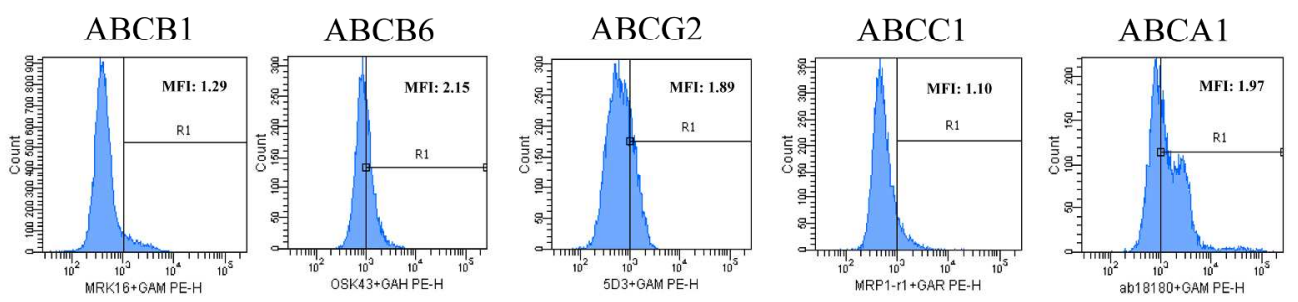

$239 \times 149 \mathrm{~mm}(300 \times 300 \mathrm{DPI})$

30

31

32

33

34

35

36

37

38

39

40

41

42

43

44

45

46

47

48

49

50

51

52

53

54

55

56

57

58

59

60

John Wiley and Sons, Inc. 
A

MSCI
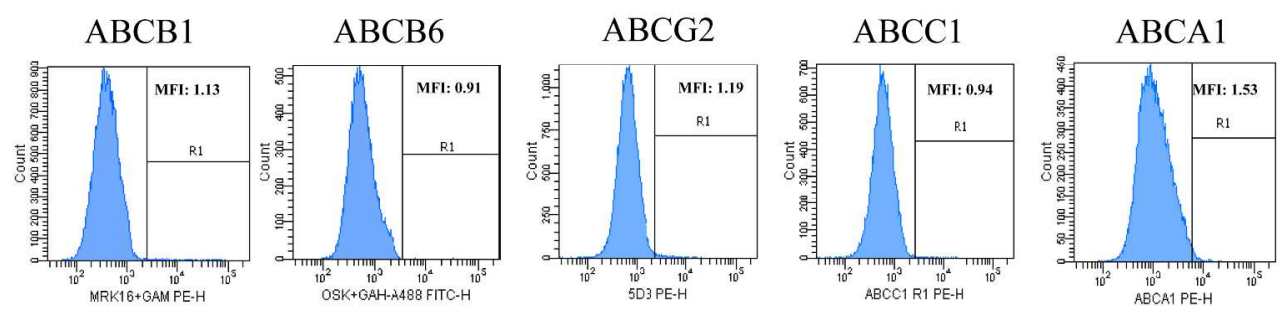

B
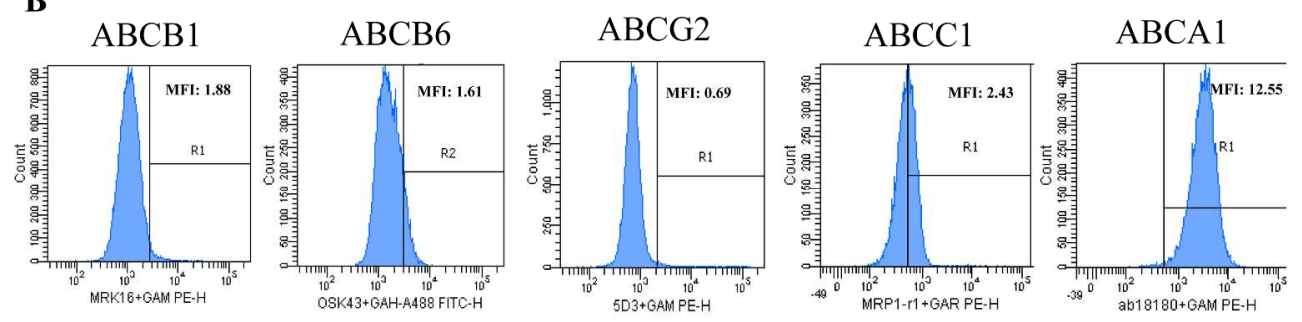

$238 \times 146 \mathrm{~mm}(300 \times 300 \mathrm{DPI})$

29

30

31

32

33

34

35

36

37

38

39

40

41

42

43

44

45

46

47

48

49

50

51

52

53

54

55

56

57

58

59

60

John Wiley and Sons, Inc. 


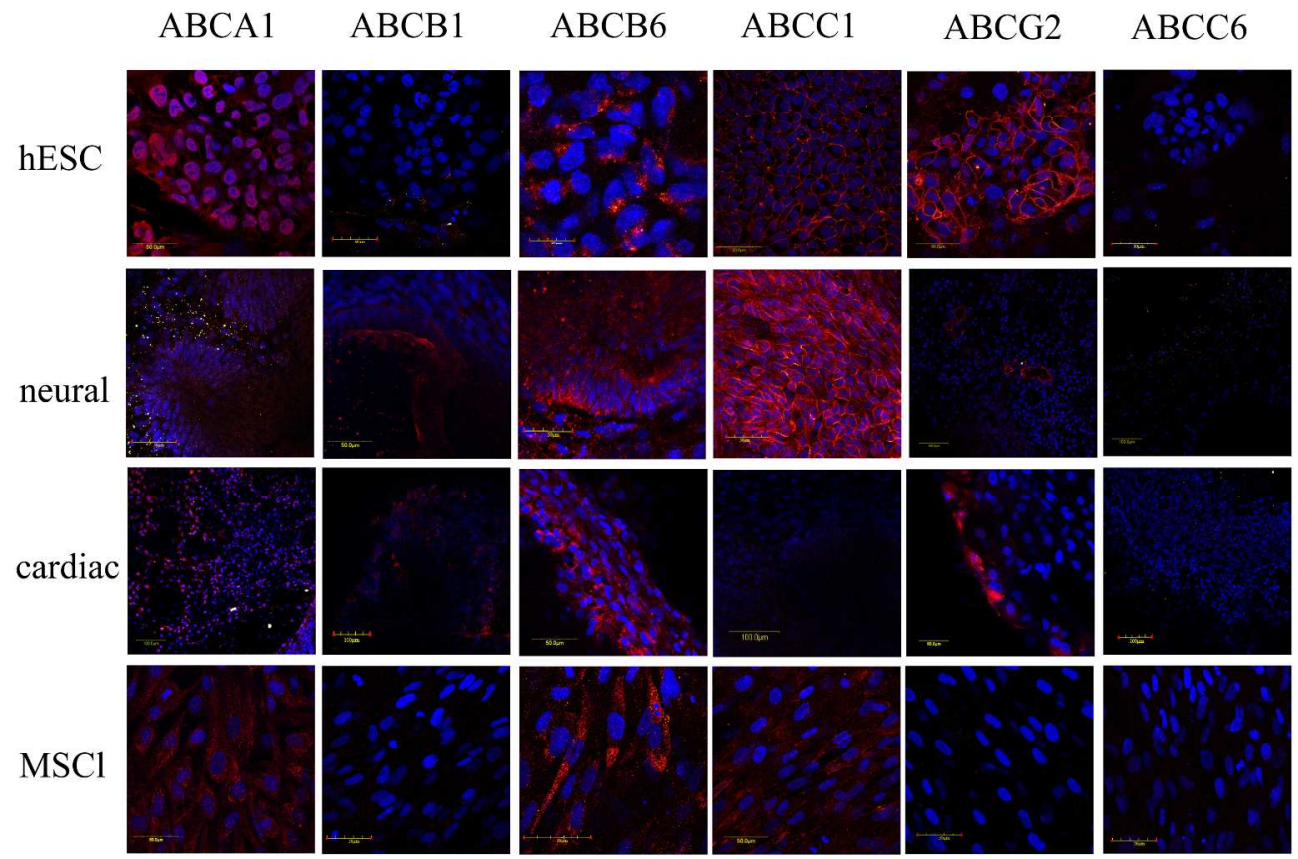

$253 \times 171 \mathrm{~mm}(300 \times 300 \mathrm{DPI})$

John Wiley and Sons, Inc. 


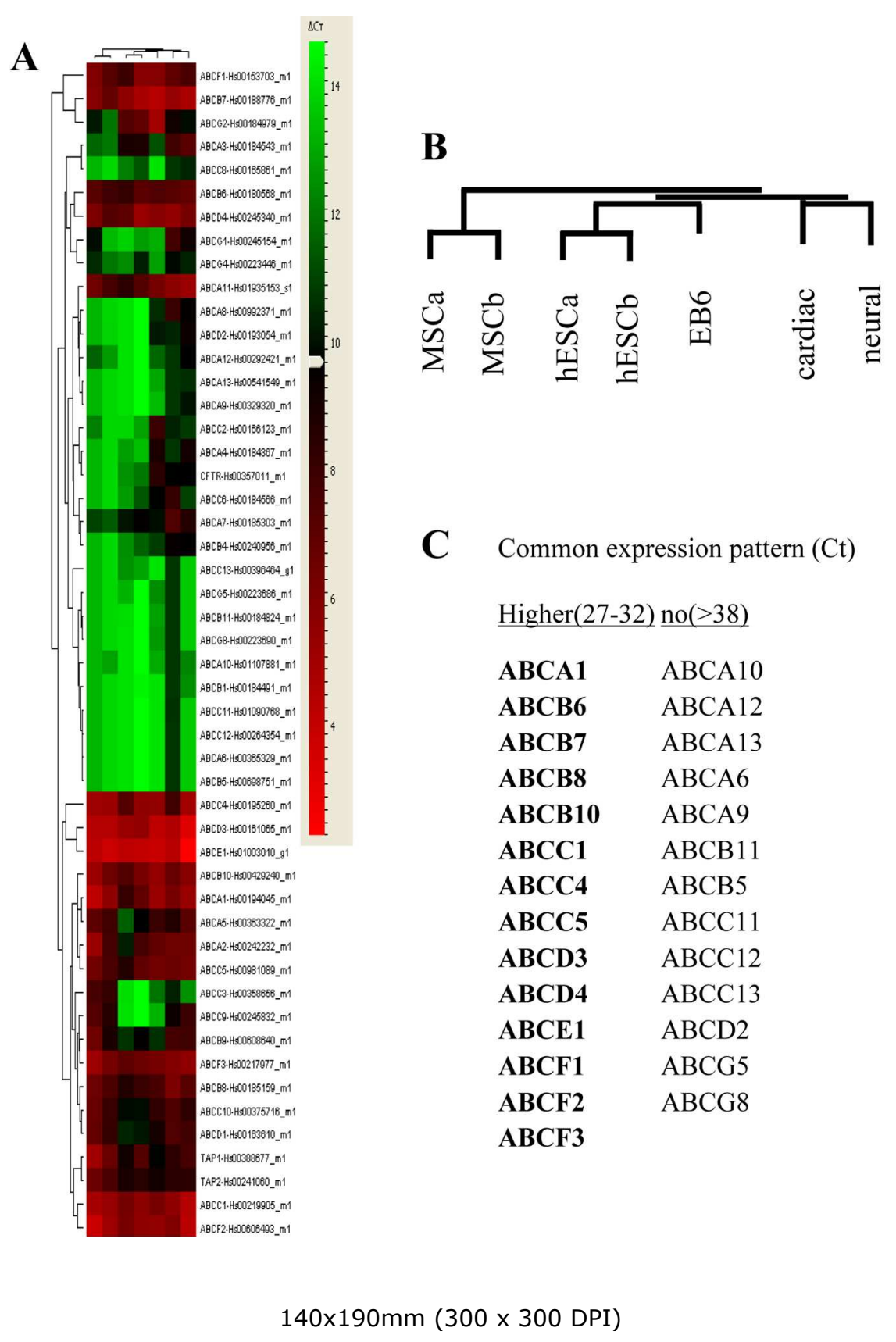




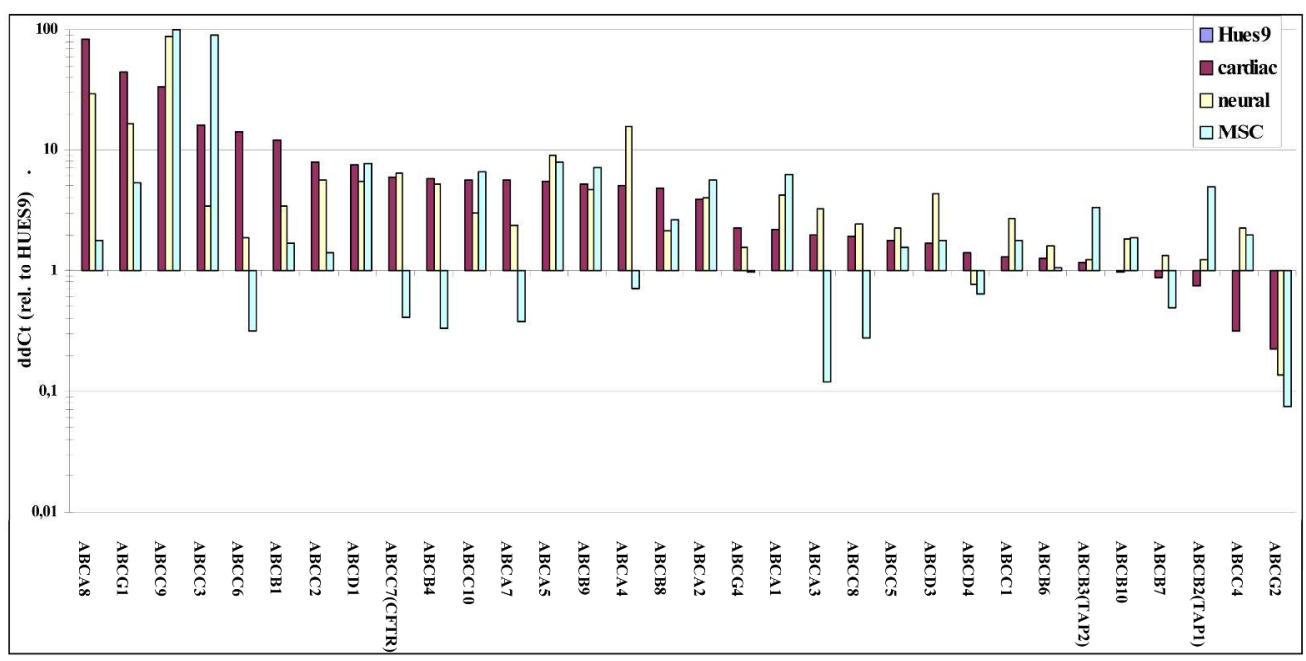

$253 \times 129 \mathrm{~mm}(300 \times 300 \mathrm{DPI})$

John Wiley and Sons, Inc. 


\section{Suppl table 1}

\begin{tabular}{|c|c|c|c|}
\hline $\begin{array}{l}\text { ABC protein } \\
\text { (Gene symbol) }\end{array}$ & Function - potential substrates & $\begin{array}{l}\text { Localization } \\
\text { (protein) }\end{array}$ & Tissue distribution \\
\hline ABCA1 & HDL biogenesis -glycero-phospholipid compounds & $\mathrm{PM} /$ Golgi/lyso & Broad \\
\hline $\mathrm{ABCA} 2$ & Control of lipid transport - unknown & PM/Golgi/lyso & Brain- Broad \\
\hline $\mathrm{ABCA} 3$ & $\begin{array}{l}\text { Lung surfactant production- glycero-phospholipid } \\
\text { compounds }\end{array}$ & PM/Lysosome & Lung- Broad \\
\hline $\mathrm{ABCA} 4$ & Retinal integrity- glycero-phospholipid compounds & PM & Retina \\
\hline ABCA5 & Control of lipid transport - unknown & Endolysosome & Broad -Heart? \\
\hline ABCA6 & Control of lipid transport - unknown & PM & Broad \\
\hline ABCA7 & $\begin{array}{l}\text { Phagocytosis (?)-glycero-phospholipid } \\
\text { compounds/ceramide backbone lipids }\end{array}$ & PM & Broad \\
\hline ABCA8 & Control of lipid transport - unknown & PM & Broad \\
\hline ABCA9 & Control of lipid transport - unknown & PM & Broad \\
\hline ABCA10 & Control of lipid transport - unknown & PM & Broad \\
\hline ABCA12 & Skin lipid barrier formation- ceramide backbone lipids & PM & Keratinocytes/skin \\
\hline $\mathrm{ABCA13}$ & Control of lipid transport - unknown & PM & Broad \\
\hline $\begin{array}{l}\text { ABCB1 } \\
\text { (MDR1) }\end{array}$ & Multidrug resistance - drugs and metabolites & PM & $\begin{array}{l}\text { Tissue barriers- } \\
\text { Broad-cancer }\end{array}$ \\
\hline ABCB2 (TAP1) & Antigen presentation - peptide & ER & Blood \\
\hline ABCB3 (TAP2) & Antigen presentation - peptide & ER & Blood \\
\hline $\mathrm{ABCB} 4$ & Phospholipid flippase - lipids & PM & Liver canaliculus \\
\hline ABCB5 & Multidrug resisitance - drugs & PM & Broad-melanomas \\
\hline $\mathrm{ABCB} 6$ & Heme and porphyrin transport? & Mito/lyso/PM? & Broad \\
\hline $\mathrm{ABCB} 7$ & Metal homeostasis - heme & Mitochondria & Broad \\
\hline ABCB8 & Mitochondrial iron homeostasis - unknown & Mitochondria & Broad \\
\hline ABCB9 & Antigen presentation-peptide? & Lysosomal & Testis-broad \\
\hline ABCB10 & $\begin{array}{l}\text { Mitochondrial transport functions related to heme } \\
\text { biosynthesis? }\end{array}$ & Mitochondria & Broad \\
\hline $\begin{array}{l}\mathrm{ABCC} 1 \\
\text { (MRP1) }\end{array}$ & Multidrug resistance-drugs/metabolites/ organic anions & PM & $\begin{array}{l}\text { Tissue barriers - } \\
\text { broad - cancer }\end{array}$ \\
\hline $\mathrm{ABCC} 2$ & Multidrug resistance - drugs/metabolites/organic anions & PM & Broad-liver \\
\hline $\mathrm{ABCC} 3$ & Multidrug resistance - drugs/metabolites/ organic anions & PM & Broad \\
\hline $\mathrm{ABCC} 4$ & Multidrug resistance - drugs/metabolites/organic anions & PM & Broad \\
\hline $\mathrm{ABCC} 5$ & Multidrug resistance - drugs/metabolites/ organic anions & PM & Broad \\
\hline $\mathrm{ABCC} 6$ & Tissue metabolism metabolites/organic anions & PM & liver, broad \\
\hline ABCC7 (CFTR) & Cystic fibrosis - chloride ion channel & $\mathrm{PM}$ & Ephitelial cells \\
\hline ABCC8 (SUR1) & Sulfonylurea receptor - potassium channel & PM & Pancreas \\
\hline ABCC9 (SUR2) & Sulfonylurea receptor - potassium channel & PM & $\begin{array}{l}\text { Smooth/cardiac } \\
\text { muscle }\end{array}$ \\
\hline $\mathrm{ABCC} 10$ & Multidrug resistance - drugs/metabolites/organic anions & PM & Broad \\
\hline $\mathrm{ABCC} 11$ & Multidrug resistance - drugs/metabolites/ organic anions & $\mathrm{PM}$ & Broad - liver \\
\hline $\mathrm{ABCC} 12$ & Multidrug resistance - drugs/metabolites & PM & Broad \\
\hline $\mathrm{ABCD} 1$ & acyl-CoA ester transporter? & Peroxisome & Broad \\
\hline $\mathrm{ABCD} 2$ & Long chain fatty acids? - unknown & Peroxisome & Broad \\
\hline $\mathrm{ABCD} 3$ & Long chain fatty acids? - unknown & Peroxisome & Broad \\
\hline $\mathrm{ABCD} 4$ & Long chain fatty acids? - unknown & Peroxisome & Broad \\
\hline$A B C E 1^{*}$ & RNase L inhibitor & Cytoplasm & Broad \\
\hline$A B C F 1^{*}$ & Translation initiation/Inflammation & Cytoplasm & Broad \\
\hline$A B C F 2 *$ & Inflammation? & Cytoplasm & Broad \\
\hline$A B C F 3^{*}$ & Inflammation? & Cytoplasm & Broad \\
\hline ABCG1 & Lipid homeostasis & PM & Broad/macrophage \\
\hline $\mathrm{ABCG} 2$ & Multidrug resistance - drugs/metabolites & PM & $\begin{array}{l}\text { Tissue barriers-stem } \\
\text { cells-cancer }\end{array}$ \\
\hline ABCG5 & Sterol transporter & PM & Liver/colon/intestine \\
\hline ABCG8 & Sterol transporter & PM & Liver/colon/intestine \\
\hline
\end{tabular}

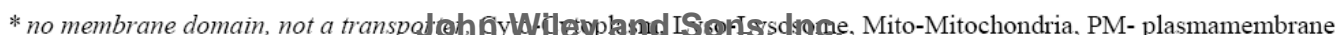


Suppl fig 1

Undifferentiated Embryoid body Adherent suspension

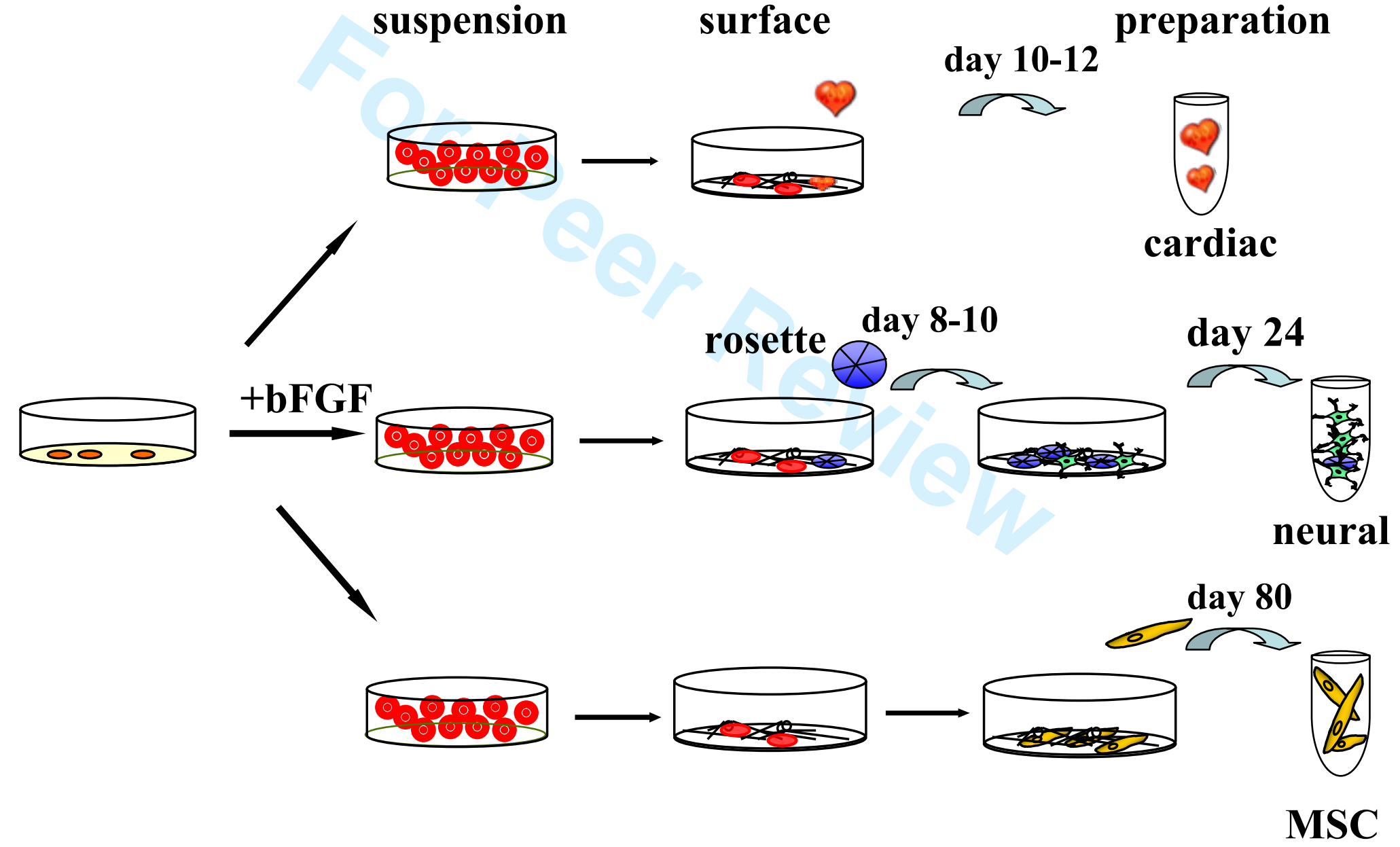




\section{Suppl table 2}

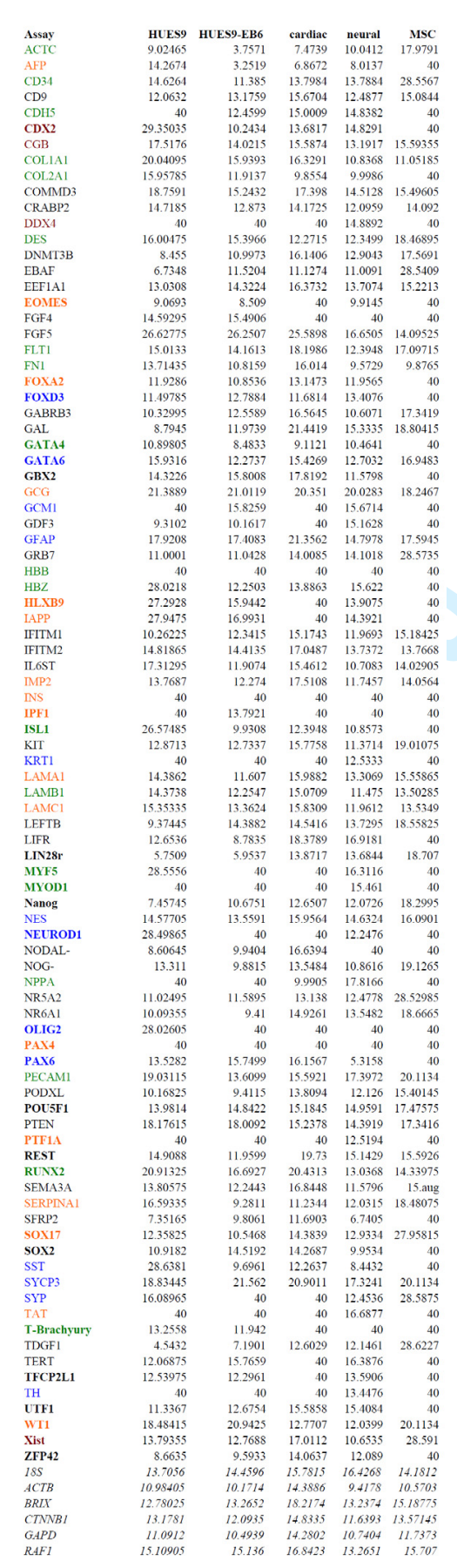




\section{Suppl fig 2B}

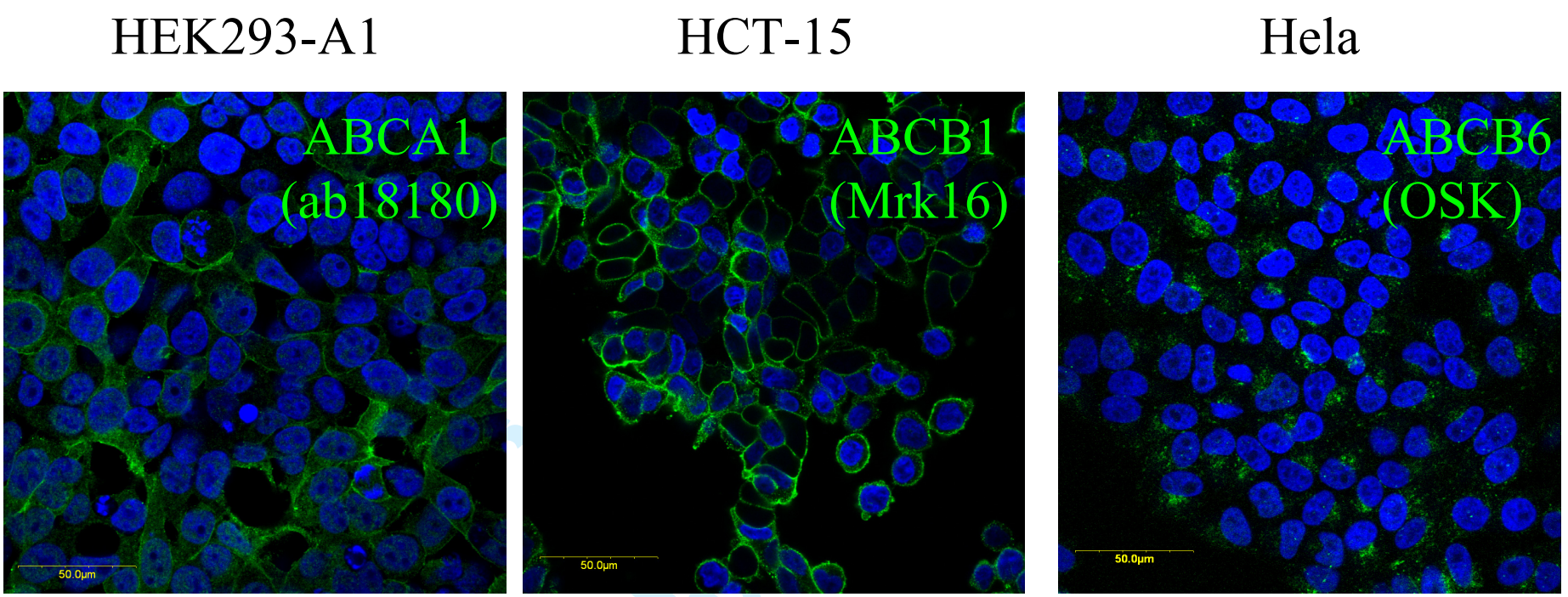

HEK293-C1

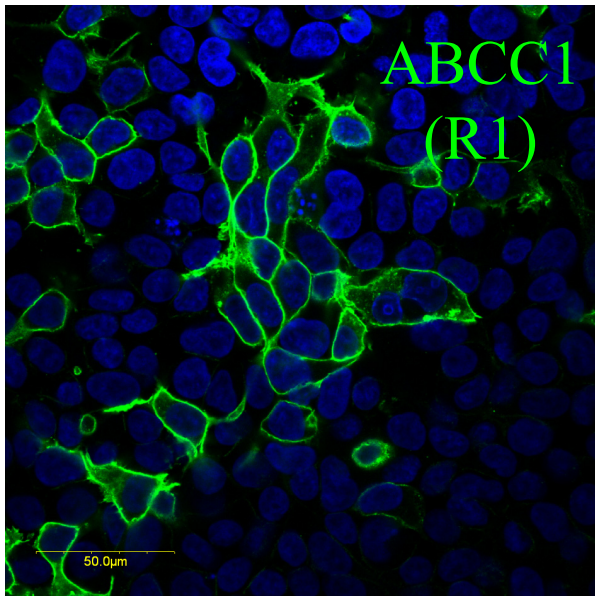

MDCK-C6

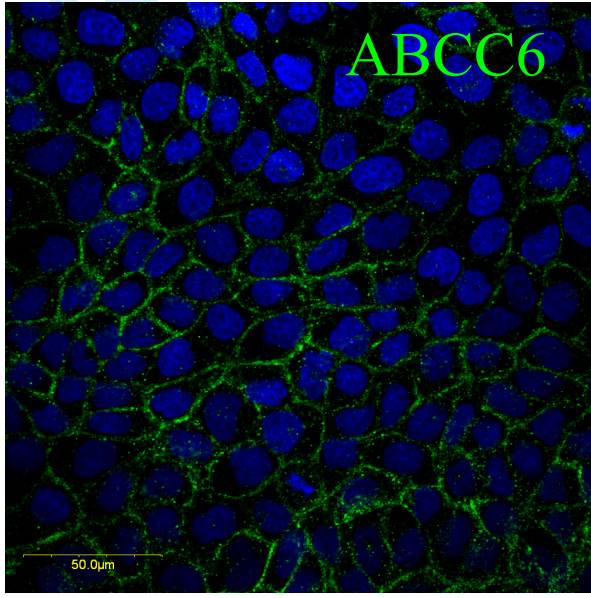


Suppl table 3

\begin{tabular}{|c|c|c|c|c|c|}
\hline Assay & HUES9 & HUES9-EB6 & cardiac & neural & MSC \\
\hline ABCA1 & 31.0396 & 28.9795 & 33.4435 & 29.5752 & 29.23925 \\
\hline ABCA10 & 40 & 37.5343 & 40 & 37.3005 & 38.8018 \\
\hline ABCA11 & 31.3768 & 30.068 & 32.8675 & 29.4832 & 31.4277 \\
\hline ABCA12 & 40 & 35.4942 & 40 & 34.0227 & 36.8993 \\
\hline ABCA13 & 40 & 37.4678 & 40 & 34.9098 & 40 \\
\hline ABCA2 & 32.55955 & 30.6405 & 33.7526 & 30.7606 & 30.81145 \\
\hline ABCA3 & 32.4187 & 35.0962 & 35.1046 & 31.4391 & 36.60345 \\
\hline ABCA4 & 37.36255 & 32.6502 & 40 & 33.397 & 40 \\
\hline ABCA5 & 34.1788 & 31.7675 & 35.9395 & 31.3826 & 31.76785 \\
\hline ABCA6 & 40 & 40 & 40 & 40 & 40 \\
\hline ABCA7 & 33.4291 & 33.7757 & 34.6049 & 32.8954 & 35.6226 \\
\hline ABCA8 & 40 & 34.3586 & 35.2636 & 33.8209 & 40 \\
\hline ABCA9 & 40 & 37.8515 & 40 & 34.3748 & 40 \\
\hline ABCB1 & 38.93785 & 40 & 39.9477 & 36.8391 & 40 \\
\hline ABCB10 & 30.30915 & 29.2057 & 33.9407 & 30.0782 & 30.2309 \\
\hline ABCB11 & 40 & 37.3311 & 40 & 40 & 40 \\
\hline ABCB2(TAP1) & 31.81895 & 33.5447 & 35.6379 & 31.9229 & 30.23265 \\
\hline ABCB3(TAP2) & 32.2998 & 32.9817 & 35.7159 & 32.6841 & 31.4224 \\
\hline ABCB4 & 35.6415 & 34.701 & 36.7285 & 33.911 & 40 \\
\hline ABCB5 & 40 & 40 & 40 & 40 & 40 \\
\hline ABCB6 & 31.17235 & 31.1244 & 34.3911 & 31.094 & 31.8473 \\
\hline ABCB7 & 28.77805 & 28.2054 & 32.6029 & 29.0442 & 30.66375 \\
\hline АВСВ8 & 31.90185 & 31.3394 & 33.2875 & 31.4903 & 31.34925 \\
\hline АВСВ9 & 33.7305 & 34.4125 & 34.9418 & 32.1476 & 32.058 \\
\hline $\mathrm{ABCC} 1$ & 29.50465 & 30.0096 & 32.7507 & 28.7592 & 29.4335 \\
\hline $\mathrm{ABCC} 10$ & 33.46015 & 32.0802 & 34.6533 & 32.6083 & 31.72 \\
\hline ABCC11 & 40 & 40 & 40 & 40 & 40 \\
\hline$A B C C$ & 40 & 40 & 40 & 40 & 40 \\
\hline $\mathrm{ABCC} 13$ & 36.34535 & 40 & 40 & 40 & 40 \\
\hline $\mathrm{ABCC} 2$ & 37.2038 & 31.7999 & 38.2795 & 35.1388 & 38.7928 \\
\hline $\mathrm{ABCC} 3$ & 39.61925 & 35.7791 & 38.2363 & 37.5311 & 32.25395 \\
\hline $\mathrm{ABCC} 4$ & 29.94055 & 29.1956 & 35.0429 & 29.2441 & 29.50745 \\
\hline $\mathrm{ABCC} 5$ & 31.30305 & 30.1312 & 33.886 & 30.6196 & 31.31055 \\
\hline$A B C C$ & 35.98755 & 5331 & 35.3876 & 35.9696 & 40 \\
\hline ABCC7(CFTR) & 35.9023 & 32.2108 & 37.0983 & 33.9348 & 40 \\
\hline $\mathrm{ABCC} 8$ & 35.3508 & 40 & 40 & 34.7305 & 40 \\
\hline $\mathrm{ABCC} 9$ & 40 & 37.6908 & 36.5667 & 32.2507 & 32.30205 \\
\hline ABCD1 & 33.817 & 32.8194 & 34.5989 & 32.0951 & 31.8303 \\
\hline $\mathrm{ABCD} 2$ & 40 & 33.9739 & 38.0008 & 33.6023 & 39.4229 \\
\hline $\mathrm{ABCD} 3$ & 28.8863 & 738 & 31. & 27 & 28.8246 \\
\hline $\mathrm{ABCD} 4$ & 29.6969 & 29.5948 & 32.6149 & 30.5656 & 31.02785 \\
\hline ABCE1 & 27.68005 & 27.6752 & 31.5605 & 26.5991 & 28.ápr \\
\hline ABCF1 & 30.43265 & 29.5735 & 34.1468 & 31.8244 & 30.94155 \\
\hline ABCF2 & 29.4323 & 29.237 & 33.205 & 28.58 & 28.84575 \\
\hline $\mathrm{ABCF} 3$ & 30.36395 & 30.0931 & 33.1239 & 29.77 & 30.05705 \\
\hline$A B C C$ & 37.55575 & 37.6022 & 35.0021 & 33.4688 & 36.36145 \\
\hline ABCG2 & 30.6401 & 28.7107 & 37.1048 & 34.228 & 35.7986 \\
\hline ABCG4 & 34.9418 & 29.6009 & 37.0756 & 34.6503 & 35.6558 \\
\hline & 38.887 & & 40 & 40 & 40 \\
\hline ABCG8 & 40 & 37.1797 & 40 & 40 & 40 \\
\hline $18 \mathrm{~S}$ & 14.1835 & 14.1306 & 16.2589 & 15.2277 & 14.23325 \\
\hline ACTB & 21.99195 & 21.7459 & 26.1247 & 21.3886 & 21.46675 \\
\hline GAPDH & 23.2931 & 22.6533 & 26.8245 & 23.6486 & 23.33645 \\
\hline GUSB & 29.8687 & 28.8575 & 33.3999 & 30.6198 & 30.85525 \\
\hline HMBS & 29.96835 & 30.5808 & 33.7787 & 31.3743 & 31.0917 \\
\hline HPRT1 & 26.02505 & 26.2342 & 31.099 & 27.2207 & 27.99935 \\
\hline PGK1 & 24.86525 & 24.9142 & 27.0533 & 24.7633 & 26.20165 \\
\hline POLR2A & 29.03875 & 28.0373 & 32.8166 & 28.4542 & 29.20705 \\
\hline PPIA & 23.60035 & 23.8241 & 27.2754 & 24.3327 & 24.40375 \\
\hline$R P L P O$ & 24.1812 & 24.0738 & 26.5179 & 24.1969 & 24.5465 \\
\hline$T B P$ & 29.30135 & 28.6037 & 33.2622 & 29.4393 & 29.942 \\
\hline & & & & & \\
\hline
\end{tabular}

John Wiley and Sons, Inc. 
10-100x higher expression relative to hESC

\begin{tabular}{llllll} 
Cardiac & \multicolumn{3}{c}{ Neural } & \multicolumn{3}{l}{ MSC } \\
\hline ABCA8 & 83.6 & ABCC9 & 87.8 & ABCC9 & 99.2 \\
ABCG1 & 44.7 & ABCA8 & 29.6 & ABCC3 & 90.2 \\
ABCC9 & 33.9 & ABCG1 & 16.8 & & \\
ABCC3 & 16.3 & ABCA4 & 16.0 & & \\
ABCC6 & 13.8 & & & & \\
ABCB1 & 11.9 & & & &
\end{tabular}

$<2$ or lower expression relative to $\mathrm{hESC}$

\begin{tabular}{ll} 
Cardiac & \\
\hline $\mathrm{ABCA} 3$ & 1.98 \\
$\mathrm{ABCC} 8$ & 1.95 \\
$\mathrm{ABCC} 5$ & 1.79 \\
$\mathrm{ABCD} 3$ & 1.69 \\
$\mathrm{ABCD} 4$ & 1.43 \\
$\mathrm{ABCC} 1$ & 1.31 \\
$\mathrm{ABCB} 6$ & 1.27 \\
$\mathrm{ABCB} 3$ & 1.19 \\
$\mathrm{ABCB} 10$ & 0.96 \\
$\mathrm{ABCB} 7$ & 0.87 \\
$\mathrm{ABCB} 2$ & 0.74 \\
$\mathrm{ABCC} 4$ & 0.32 \\
$\mathrm{ABCG} 2$ & 0.23
\end{tabular}

\section{2-10x higher expression relative to $\mathrm{hESC}$}

\begin{tabular}{llllll} 
Cardiac & \multicolumn{3}{c}{ Neural } & MSC \\
\hline ABCC2 & 7.77 & ABCA5 & 9.04 & ABCA5 & 7.89 \\
ABCD1 & 7.39 & ABCC7 & 6.40 & ABCD1 & 7.61 \\
ABCC7 & 5.98 & ABCC2 & 5.62 & ABCB9 & 7.10 \\
ABCB4 & 5.71 & ABCD1 & 5.45 & ABCC10 & 6.48 \\
ABCA7 & 5.58 & ABCB4 & 5.23 & ABCA1 & 6.17 \\
ABCC10 & 5.58 & ABCB9 & 4.65 & ABCB2 & 4.96 \\
ABCA5 & 5.48 & ABCD3 & 4.35 & ABCA2 & 5.62 \\
ABCB9 & 5.16 & ABCA1 & 4.21 & ABCG1 & 5.37 \\
ABCA4 & 5.06 & ABCA2 & 4.00 & ABCB3 & 3.35 \\
ABCA2 & 3.86 & ABCB1 & 3.47 & ABCB8 & 2.62 \\
ABCB8 & 4.76 & ABCC3 & 3.45 & ABCC4 & 2.01 \\
ABCG4 & 2.27 & ABCA3 & 3.28 & & \\
ABCA1 & 2.22 & ABCC10 & 3.00 & & \\
& & ABCC1 & 2.70 & & \\
& & ABCC8 & 2.45 & &
\end{tabular}




\section{Supplementary methods}

\section{Cell cultures and differentiation}

ABCA1 overexpressing HEK 293 (HEK 293-A1), ABCC1 overexpressing HEK 293 (HEK 293-A1), ABCC6 overexpressing MDCK (MDCK-C6), and HeLa (endogenously expressing ABCB6) cell lines were cultured in Dulbecco's modified Eagle's medium (DMEM) supplemented with $10 \%$ of fetal calf serum, $1 \%$ of L-Glutamine, and $1 \%$ of penicillin/streptomycin (Life Technologies) and were used as positive controls for immunostainings of respective $\mathrm{ABC}$ transporter proteins. HCT-15, ABCA1, ABCB1 and ABCC1 overexpressing HL60 cell lines (HL60-ABCA1, HL60-ABCB1 and HL60-ABCC1 respectively) were cultured in RPMI1640 Medium, supplemented with $10 \%$ of fetal calf serum, $1 \%$ of L-Glutamine, and $1 \%$ of penicillin/streptomycin (Life Technologies) and was used as a positive control cell line for respective $\mathrm{ABC}$ transporter proteins stainings.

HUES9 cells were cultured on a feeder layer of mitotically inactivated mouse embryonic fibroblasts (mitomycin-C (Sigma) and Millipore - CF1) on tissue culture 6- well plates (Nunc). The culture medium consisted of 15\% Knockout Serum Replacement (Gibco), 80\% Knockout Dulbecco Modified Eagle Medium (Gibco), $1 \mathrm{mM}$ Glutamax-I (Gibco), $0.1 \mathrm{mM}$ beta-mercaptoethanol, $1 \%$ nonessential amino acids, and $4 \mathrm{ng} / \mathrm{mL}$ human fibroblast growth factor (Invitrogen). Cells were re-plated every second day on fresh feeder layer by enzymatic dissociation with $0,025 \%$ trypsin-EDTA (Invitrogen).

\section{Differentiation of Human Embryonic Stem Cells (HUES9)}

Spontaneous differentiation of the HUES9 cells was performed via embryoid body (EB) formation system in suspension. Undifferentiated cells were passaged enzymatically with collagenase-IV and were transferred to Poly-2 Hydroxyethyl-methacrylate (Sigma-Aldrich) treated Petri dishes; therefore the spontaneous aggregation of cells and embryoid body formation could be obtained. EBs were cultured in differentiation medium consisting of Ko DMEM supplemented with $20 \%$ non heat inactivated fetal bovine serum, $1 \%$ nonessential amino acids, $1 \mathrm{mML}$-glutamine, and $0.1 \mathrm{mM}$ beta-mercaptoethanol (Invitrogen) for six days, medium was changed daily. In case of neuronal differentiation, similarly to undifferentiated cell culture medium, $4 \mathrm{ng} / \mathrm{ml} \mathrm{bFGF}$ was added to the culture media during EB formation. After 6 days, the embryoid bodies were placed onto gelatin-coated 24- well plates, where they continued a further spontaneous differentiation process in D-MEM supplemented with $10 \%$ of fetal calf serum, $1 \%$ of L-Glutamine, medium was changed on every other day. After few 
days of culturing under the aforementioned conditions several cell types were formed in the gelatin-coated culture dishes, including cardiomyocytes, neuronal progenitors and fibroblastlike cells. These cells were identified by morphological signs under phase contrast light microscope and mechanically passaged for further propagation in D-MEM supplemented with $10 \%$ of fetal calf serum, $1 \%$ of L-Glutamine.

\section{Flow cytometry and immuno -cytochemical labeling}

For flow cytometric analysis single cell suspensions were split into two portions. First portions of cells remained intact and were labeled in PBS containing $0.5 \%$ bovine serum albumin with appropriate antibodies. The second samples were fixed and permeabilized by the Fix\&Perm (Invitrogen) solution according to the manufacturer's instruction before staining procedure. The labeling was accomplished with specific antibodies listed below in the table. In all hESC samples an anti-mouse Sca-1 (Ly-6A/E) (FITC or PE, BD Pharmingen) antibody was employed for gating out the positively labeled mouse feeder cells. Non-viable cells were excluded by 7AAD staining. Samples were analyzed by a BD FACSCantoII flow cytometer (Becton Dickinson Immunocytometry Systems [BDIS]), equipped with a $488 \mathrm{~nm}$ diode laser (emission filters: 585/42 nm for PE; 530/30 for FITC, 670LP for 7AAD) and a $633 \mathrm{~nm}$ He-Ne laser (emission filters: 660/20 for APC) with BD FACSDiva 6.1.2 Software (BDIS).

For confocal microscopy the cells were seeded onto eight-well Nunc Lab-Tek II Chambered Coverglass (Nalge Nunc International), and fixed with $4 \%$ paraformaldehyde in Dulbecco's modified PBS (DPBS) or Fix\&Perm A solution for 15 min at room temperature. Occasionally 5 min methanol treatment was used (see the Table). Following further washing steps with DPBS, nonspecific antibody binding was blocked for $1 \mathrm{~h}$ at room temperature in blocking solution (DPBS containing $2 \mathrm{mg} / \mathrm{ml}$ bovine serum albumin, $1 \%$ fish gelatin, $5 \%$ goat serum) and with (Complete) or without $0.1 \%$ Triton-X 100 (Complete wo Tx) or Fix\&Perm B solution. The cells were then incubated for $1 \mathrm{~h}$ at room temperature with specific monoclonal antibodies in proper blocking solutions. After washing with DPBS, the samples were incubated for $1 \mathrm{~h}$ at room temperature with secondary antibodies. After removing secondary antibody solutions and washing steps Hoechst33342 (Invitrogen) was used for nuclear staining. 
Table of antibodies:

\begin{tabular}{|c|c|c|c|c|}
\hline Primary antibody & Manufacturer & Dilution & $\begin{array}{l}\text { Secondary } \\
\text { antibody }\end{array}$ & Labeling methods \\
\hline \multicolumn{5}{|l|}{$F A C S$} \\
\hline $\begin{array}{l}\overline{\text { Sca-1 }}(\mathrm{Ly}-6 \mathrm{~A} / \mathrm{E}) \\
\text { FITC or PE }\end{array}$ & BD Pharmingen & $1: 25$ & - & Intact \\
\hline SSEA4-APC & R\&D Systems & $1: 50$ & - & Intact \\
\hline PODXL-PE & R\&D Systems & $1: 10$ & - & Intact \\
\hline $\begin{array}{l}\text { Anti ABCG2 } \\
\text { 5D3-CD338 }\end{array}$ & BD Pharmingen & $1: 125$ & Mouse IgG2b-PE & $\begin{array}{l}\text { Intact+Ko143 or } \\
\text { Fix\&Perm+Ko143 }\end{array}$ \\
\hline $\begin{array}{l}\text { Anti ABCB1 } \\
\text { MRK16 }\end{array}$ & $\begin{array}{l}\text { Alexis } \\
\text { Biochemicals }\end{array}$ & $1: 100$ & Mouse IgG2a-PE & Intact or Fix\&Perm \\
\hline $\begin{array}{l}\text { Anti-Lan } \\
\text { clone: OSK43 }\end{array}$ & $\begin{array}{l}\text { Provided by } \mathrm{H} . \\
\text { Takahashi }\end{array}$ & $1: 70$ & $\begin{array}{l}\text { IgG+M-A488 or } \\
\text { PE }\end{array}$ & Intact or Fix\&Perm \\
\hline $\begin{array}{l}\text { Anti ABCC1 } \\
\text { clone: MRPr1 }\end{array}$ & Abcam & $1: 25$ & Rat IgG2a-PE & Intact or Fix\&Perm \\
\hline $\begin{array}{l}\text { Anti-ABCA1 } \\
\text { clone:AB.H10 }\end{array}$ & Abcam & $1: 50$ & Mouse IgG1-PE & Intact or Fix\&Perm \\
\hline \multicolumn{5}{|l|}{ Immuncytochemistry } \\
\hline $\begin{array}{l}\text { Anti ABCG2 } \\
\text { 5D3-CD338 }\end{array}$ & $\begin{array}{l}\text { BD. } \\
\text { Pharmingen }\end{array}$ & $1: 250$ & Mouse IgG2b-PE & Fix\&Perm +Ko143 \\
\hline $\begin{array}{l}\text { Anti ABCB1 } \\
\text { MRK16 }\end{array}$ & $\begin{array}{l}\text { Alexis } \\
\text { Biochemicals }\end{array}$ & $1: 100$ & Mouse IgG2a-PE & $\begin{array}{l}4 \% \text { PFA } \\
\text { Complete wo Tx }\end{array}$ \\
\hline $\begin{array}{l}\text { Anti-Lan } \\
\text { clone: OSK43 }\end{array}$ & $\begin{array}{l}\text { Provided by H. } \\
\text { Takahashi }\end{array}$ & $1: 100$ & $\begin{array}{l}\text { IgG+M-A } 488 \text { or } \\
\text { PE }\end{array}$ & Fix\&Perm \\
\hline $\begin{array}{l}\text { Anti ABCC1 } \\
\text { clone: MRPr1 }\end{array}$ & Abcam & $1: 25$ & Rat IgG2a-PE & $\begin{array}{l}4 \% \text { PFA+ } 5 \text { min } \\
\text { methanol } \\
\text { Complete }\end{array}$ \\
\hline $\begin{array}{l}\text { Anti-ABCA1 } \\
\text { clone:AB.H10 }\end{array}$ & Abcam & $1: 200$ & Mouse IgG1-PE & Fix\&Perm \\
\hline Anti ABCC6 M6II-7 & $\begin{array}{l}\text { Pierce } \\
\text { Antibodies }\end{array}$ & $1: 100$ & Rat IgG2a-A488 & $\begin{array}{l}4 \% \text { PFA }+5 \text { min } \\
\text { methanol Complete }\end{array}$ \\
\hline Oct4 & SantaCruz & $1: 50$ & Mouse IgG-A488 & $\begin{array}{l}4 \% \text { PFA } \\
\text { Complete }\end{array}$ \\
\hline Nanog & RnD Systems & $1: 10$ & Goat-cy3 & $\begin{array}{l}\text { 4\%PFA } \\
\text { Complete }\end{array}$ \\
\hline SSEA4 & RnD Systems & $1: 50$ & Mouse IgG-A488 & $\begin{array}{l}\text { 4\%PFA } \\
\text { Complete wo Tx }\end{array}$ \\
\hline PODXL & RnD Systems & $1: 10$ & Mouse IgG-A488 & $\begin{array}{l}\% \text { PFA } \\
\text { Complete wo Tx }\end{array}$ \\
\hline cardiac Troponin-I & Sigma & $1: 300$ & Mouse IgG-A568 & $\begin{array}{l}\text { 4\%PFA } \\
\text { Complete }\end{array}$ \\
\hline$\beta$-III Tubulin & RnD Systems & $1: 2000$ & Mouse IgG-A488 & $\begin{array}{l}\% \text { PFA } \\
\text { Complete }\end{array}$ \\
\hline CD-44-FITC & BD Pharmigen & $1: 10$ & - & $\begin{array}{l}\text { 4\%PFA } \\
\text { Complete wo Tx }\end{array}$ \\
\hline Nestin & Abcam & $1: 250$ & Rabbit IgG-A564 & $\begin{array}{l}4 \% \text { PFA } \\
\text { Complete }\end{array}$ \\
\hline
\end{tabular}

